\title{
The European aerosol budget in 2006
}

\author{
J. M. J. Aan de Brugh ${ }^{1,2}$, M. Schaap ${ }^{2}$, E. Vignati ${ }^{3}$, F. Dentener ${ }^{3}$, M. Kahnert ${ }^{4}$, M. Sofiev ${ }^{5}$, V. Huijnen ${ }^{6}$, and \\ M. C. Krol ${ }^{1,7}$ \\ ${ }^{1}$ Meteorology and Air Quality Section, Wageningen University, Wageningen, The Netherlands \\ ${ }^{2}$ TNO, Earth, Environment and Life Sciences, research group Climate, Air and Sustainability, Utrecht, The Netherlands \\ ${ }^{3}$ European Commission, Joint Research Centre, Institute for Environment and Sustainability, Ispra, Italy \\ ${ }^{4}$ Swedish Meteorological and Hydrological Institute, Norrköping, Sweden \\ ${ }^{5}$ Finnish Meteorological Institute, Helsinki, Finland \\ ${ }^{6}$ Royal Netherlands Meteorological Institute, De Bilt, The Netherlands \\ ${ }^{7}$ Institute for Marine and Atmospheric Research Utrecht, The Netherlands
}

Received: 28 June 2010 - Published in Atmos. Chem. Phys. Discuss.: 8 September 2010

Revised: 17 January 2011 - Accepted: 27 January 2011 - Published: 9 February 2011

\begin{abstract}
This paper presents the aerosol budget over Europe in 2006 calculated with the global transport model TM5 coupled to the size-resolved aerosol module M7. Comparison with ground observations indicates that the model reproduces the observed concentrations quite well with an expected slight underestimation of $\mathrm{PM}_{10}$ due to missing emissions (e.g. resuspension). We model that a little less than half of the anthropogenic aerosols emitted in Europe are exported and the rest is removed by deposition. The anthropogenic aerosols are removed mostly by rain (95\%) and only $5 \%$ is removed by dry deposition. For the larger natural aerosols, especially sea salt, a larger fraction is removed by dry processes (sea salt: $70 \%$, mineral dust: $35 \%$ ). We model transport of aerosols in the jet stream in the higher atmosphere and an import of Sahara dust from the south at high altitudes. Comparison with optical measurements shows that the model reproduces the Ångström parameter very well, which indicates a correct simulation of the aerosol size distribution. However, we underestimate the aerosol optical depth. Because the surface concentrations are close to the observations, the shortage of aerosol in the model is probably at higher altitudes. We show that the discrepancies are mainly caused by an overestimation of wet-removal rates. To match the observations, the wet-removal rates have to be scaled down by a factor of about 5. In that case the modelled ground-level concentrations of sulphate and sea salt increase by 50\% (which deteriorates the match), while other components stay roughly
\end{abstract}

Correspondence to:

J. M. J. Aan de Brugh

(joost.aandebrugh@wur.nl) the same. Finally, it is shown that in particular events, improved fire emission estimates may significantly improve the ability of the model to simulate the aerosol optical depth. We stress that discrepancies in aerosol models can be adequately analysed if all models would provide (regional) aerosol budgets, as presented in the current study.

\section{Introduction}

Aerosols have a large impact on the behaviour of our atmosphere as they influence the earth's radiation budget both directly through interaction with solar radiation (Hess et al., 1998; Haywood and Boucher, 2000; IPCC, 2007) and indirectly through altering the properties and life cycle of clouds (Rosenfeld et al., 2008; Kaufman et al., 2002). The aerosolclimate interactions are complex and the aerosol forcing is much less certain compared to the radiative effect of greenhouse gases. Hence, the combined direct and indirect aerosol effect may have masked the climate sensitivity towards an increase in greenhouse gases to an unknown extent (Anderson et al., 2003).

Exposure to particles has been associated with adverse health effects and particles are believed to be the most important air pollutant responsible for these health effect. Shortterm exposure has been associated with increased human morbidity and mortality (Brunekreef and Holgate, 2002; Dockery et al., 1993; Pope et al., 1995). Although most health studies have quantified relationships between the total aerosol mass $\left(\mathrm{PM}_{10}\right.$ or $\left.\mathrm{PM}_{2.5}\right)$ and health effects, some studies indicate that also the chemical composition of aerosols

Published by Copernicus Publications on behalf of the European Geosciences Union. 
(Hoek et al., 2002) and particle size (Stone and Donaldson, 1998) might play a significant role. To reduce the adverse health effects, air quality standards for particulate matter have been implemented in many countries. To design effective mitigation strategies, governments need to know the relationship between sources and concentrations of particulate matter. Within Europe, these relationships are traditionally obtained through source-receptor calculations (Seibert and Frank, 2004). Another way to investigate these relationships is a budget analysis as pointed out in this paper.

To better understand the relationship between the emission of aerosols and their precursors on the one hand, and the observed distribution of aerosols on the other hand, numerical models have been developed that describe the aerosol life cycle (Wilson et al., 2001; Bauer et al., 2008; de Meij et al., 2006). This presents an extremely challenging task as one needs to accurately model a host of sources, formation and transformation pathways as well as removal processes to assess aerosol composition, size distribution and mixing state. Together they determine the optical properties of aerosols as well as their ability to act as cloud condensation nuclei (CCN). Thus, to describe the full life cycle of aerosols one needs reliable (size-resolved) emission inventories and parameterisations to supply the necessary boundary conditions for the models (Vignati et al., 2010a; Dentener et al., 2006). Furthermore, one needs to represent the complex aerosol dynamics (Stier et al., 2005; Vignati et al., 2004; Wilson et al., 2001; Lee and Adams, 2010; Korhonen et al., 2008). Also, it is necessary to couple the aerosol dynamics to atmospheric chemistry to account for secondary aerosol formation, semivolatile species and the involvement of aerosols in numerous chemical cycles. Finally, one needs to consider size and composition resolved aerosol removal by wet and dry deposition processes. In the assessment of the aerosol budget, the key uncertainties arise from inaccurate emission estimates (Dentener et al., 2006; Vignati et al., 2010b) and uncertainties in the wet-removal process (Chin et al., 2000).

In a model intercomparison study, Textor et al. (2006) highlighted the poor agreement among models concerning aerosol processes, and specifically the wet removal of aerosols. The parameterisations in models are probably often tuned to produce a reasonable comparison with (satellite) observations. Unfortunately, model specific tuning often remains undocumented and arbitrarily tuning of models can have led to the huge diversity in the analysed simulations. Textor et al. (2006) showed that methodologies to analyse and compare different models are indispensable to improve our ability to model the aerosol distribution. One method that provides details about the processes that matter for aerosol modelling is a budget analysis. Budget analysis also helps to understand differences between models. An aerosol budget analysis with a bulk aerosol approach has been described in Kanakidou (2007).

The aim of this paper is threefold. First, we will present a description of the TM5 model coupled to the size-resolved aerosol module M7 and compare model results with observations. Second, we will analyse the European aerosol budget and quantify the aerosol import and export terms in the boundary layer and the free atmosphere. Thirdly, we will highlight some uncertainties that are associated with aerosol modelling. Specifically, we will address the wet-removal parameterisation in our model and focus on an anecdotical improvement of the fire-related emissions during a biomass burning episode in April-May 2006 in Eastern Europe.

\section{Model and measurements}

The quantification of the aerosol budget over Europe is performed with the global transport model TM5 (Krol et al., 2005) coupled to the aerosol dynamics module M7 (Vignati et al., 2004). To calculate the aerosol budget in the model, Europe is defined from $34^{\circ} \mathrm{N}$ to $62^{\circ} \mathrm{N}$ and from $12^{\circ} \mathrm{W}$ to $36^{\circ} \mathrm{E}$. We examine the import, export, emission and deposition of aerosols as well as chemical processes that influence particulate matter. Below we describe the main characteristics of the model with a focus to the aerosol description as well as the observations used for evaluation.

\subsection{TM5 model description}

The global horizontal resolution of the offline chemistry transport model TM5 is $6^{\circ}$ longitude by $4^{\circ}$ latitude. The vertical grid comprises 25 hybrid $\sigma$-pressure levels ranging from surface up to in the stratosphere. As the region of interest is Europe, we used TM5's two-way nested zoom capability (Krol et al., 2005; Berkvens et al., 1999) to acquire a higher resolution over Europe. The zoomed region is defined from $12^{\circ} \mathrm{N}$ to $66^{\circ} \mathrm{N}$ and from $21^{\circ} \mathrm{W}$ to $39^{\circ} \mathrm{E}$, with a resolution of $1^{\circ} \times 1^{\circ}$. Note that our definition of Europe to calculate the budget is only a part of this zoomed region. A transitional zone from $2^{\circ} \mathrm{N}$ to $74^{\circ} \mathrm{N}$ and from $36^{\circ} \mathrm{W}$ to $54^{\circ} \mathrm{E}$, with a resolution of $3^{\circ} \times 2^{\circ}$ is used to smoothen the transition (Krol et al., 2005). The vertical resolution remains the same.

The global time resolution is $90 \mathrm{~min}$. TM5 uses operator splitting, in which each process (e.g. advection, chemistry) has a time step of $45 \mathrm{~min}$. This time resolution is refined four times in the zoom region and twice in the transitional region.

TM5 uses pre-processed meteorological data from the European Centre for Medium-Range Weather Forecasts (ECMWF) (Segers et al., 2002; Bregman et al., 2003). This data includes pressure, temperature, moisture, wind fields and cloud information. TM5 operates with full chemistry and aerosols, simulating the processes: emission (Dentener et al., 2006; IPCC, 2000), deposition (Ganzeveld et al., 1998; Guelle et al., 1998), advection (Prather, 1986; Russell and Lerner, 1981), convection (Tiedtke, 1989), diffusion (Louis, 1979; Holtslag and Boville, 1993), chemistry (Houweling et al., 1998; Williams and van Noije, 2008) and photolysis 
Table 1. The seven modes in M7, their solubilities, size ranges and chemical compounds.

\begin{tabular}{|c|c|c|c|c|}
\hline$\#$ & Mode & Abbr. & Size range $(d)$ & Compounds \\
\hline 1 & Nucleation Soluble & nus & $<10 \mathrm{~nm}$ & Sulphate $\left(\mathrm{SO}_{4}^{2-}\right)$ \\
\hline 2 & Aitken Soluble & ais & $10-100 \mathrm{~nm}$ & Sulphate $\left(\mathrm{SO}_{4}^{2-}\right)$, Black carbon (BC), Organic matter (POM) \\
\hline 3 & Accumulation Soluble & acs & $100 \mathrm{~nm}-1 \mathrm{mum}$ & $\begin{array}{l}\text { Sulphate }\left(\mathrm{SO}_{4}^{2-}\right) \text {, Black carbon (BC), Organic matter (POM), Mineral } \\
\text { dust (DU), Sea salt (SS) }\end{array}$ \\
\hline 4 & Coarse Soluble & $\cos$ & $>1 \mu \mathrm{m}$ & $\begin{array}{l}\text { Sulphate }\left(\mathrm{SO}_{4}^{2-}\right) \text {, Black carbon (BC), Organic matter (POM), Mineral } \\
\text { dust (DU), Sea salt (SS) }\end{array}$ \\
\hline 5 & Aitken Insoluble & aii & $10-100 \mathrm{~nm}$ & Black carbon $(\mathrm{BC})$, Organic matter $(\mathrm{POM})$ \\
\hline 6 & Accumulation Insoluble & aci & $100 \mathrm{~nm}-1 \mu \mathrm{m}$ & Mineral dust (DU) \\
\hline 7 & Coarse Insoluble & coi & $>10 \mu \mathrm{m}$ & Mineral dust (DU) \\
\hline
\end{tabular}

(Krol and van Weele, 1997; Landgraf and Crutzen, 1998). The version used is subversion (SVN) revision 2887.

\subsection{Aerosol module description}

All aerosol processes including wet and dry removals are calculated in the model using the size resolved number and masses given by the aerosol dynamics module M7 (Vignati et al., 2004).

\subsubsection{Aerosol dynamics}

During the chemistry step of TM5, M7 is called to simulate the aerosol microphysics. M7 distinguishes seven classes (modes) of aerosols of different size and solubility. The properties of M7's aerosol modes are listed in Table 1. There are four size classes for soluble aerosols and three for insoluble aerosols. Chemical compounds can be present in various modes. For each mode, one number tracer and several tracers for the chemical compounds are subject to transport in the model for a total of twenty-five tracers.

M7 considers the modes as log-normal size distributions (von Salzen, 2006) with defined median radius $(\bar{r})$ and spread $(\sigma)$. Although aerosols may not be spherical, they are assumed spherical in the model. The size distribution of a mode looks like (Seinfeld, 1986):

$\frac{d N}{d \ln r}=\frac{N}{\sqrt{2 \pi} \ln \sigma} \cdot e^{-\frac{(\ln r-\ln \bar{r})^{2}}{2 \ln ^{2} \sigma}}$

Here, $r$ is the size, $N$ is the total aerosol number concentration, $\bar{r}$ is the median radius and $\sigma$ is the geometric standard deviation.

A mode consists of a number concentration and several component masses that are internally mixed $(N,[M])$ (Stier et al., 2005). Given the modal component masses and their densities, the total volume $(V)$ can be calculated. This volume is represented by a log-normal distribution as in Eq. (1). To derive this distribution, M7 assumes a constant standard deviation, which allows the volume per aerosol $\left(\frac{V}{N}\right)$ to determine the median radius $(\bar{r})$. The standard deviation is set to 2.00 for the coarse modes and to 1.59 for the other modes (Vignati et al., 2004). The median $\bar{r}$ is given by (Seinfeld, 1986):

$\bar{r}=\sqrt[3]{\frac{3 V}{4 \pi N} e^{-\frac{9 \ln ^{2} \sigma}{2}}}$

M7 handles the formation of new particles (binary nucleation) (Vehkamäki et al., 2002), the coagulation of particles and the condensation of sulphuric acid to existing particles. M7 ensures that the modes keep their inherent solubility by moving coated particles to the soluble (mixed) mode. The size classes are preserved by transferring mass of growing aerosols to the next mode. M7 diagnostically calculates the water attached to the soluble particles (Vignati et al., 2004).

\subsubsection{Ammonium and nitrate}

In Table 1, two compounds that are important for the aerosol budget over Europe (Putaud et al., 2004) are missing: ammonium $\left(\mathrm{NH}_{4}^{+}\right)$and nitrate $\left(\mathrm{NO}_{3}^{-}\right)$. Observations show that nitrate is very abundant, especially in the western European cold season (Schaap et al., 2002; Mehlmann and Warneck, 1995). There is a temperature-dependent equilibrium between gas phase nitric acid $\left(\mathrm{HNO}_{3}\right)$ and nitrate, dissolving into and evaporating out of the aerosol. This equilibrium also depends on the available aerosol sulphate $\left(\mathrm{SO}_{4}^{2-}\right)$ and gas phase ammonia $\left(\mathrm{NH}_{3}\right)$. M7 is not designed to model semivolatile aerosol components. We use the Equilibrium Simplified Aerosol Model (EQSAM) version 3. (Metzger et al., 2002a,b) to calculate the partitioning of ammonium nitrate between the gas and aerosol phase with the total available sulphate (of all modes). EQSAM uses a bulk aerosol approach, so it does not define in which aerosol size category the ammonium nitrate gathers. We assume that the ammonium nitrate and the water absorbed by it resides in the soluble accumulation mode. Test simulations with ISORROPIA and GMXe (Nenes et al., 1998; Pringle et al., 2010) confirm that virtually all ammonium nitrate mass is in the soluble accumulation mode. EQSAM limits the relative humidity to 99\% to exclude cloud formation (Metzger et al., 2002a). The 
aerosol associated water mass, can be sufficiently accurately reproduced by EQSAM with respect to other global model uncertainties (Metzger et al., 2002b).

\subsubsection{Dry deposition}

While gas-phase chemicals exhibit diffusive dry deposition (Ganzeveld et al., 1998; Hicks et al., 1986), aerosols are removed by diffusive dry deposition and gravity-driven sedimentation (Slinn and Slinn, 1980; Kerkweg et al., 2006). Both deposition pathways depend on the size of the aerosols.

To calculate the deposition velocities for the tracers in each mode, the lognormal distribution is used to distribute the mass and number tracers into twenty-three size bins. Each of these bins is subject to a bin-dependent deposition velocity, recalculated every three hours depending on e.g. atmospheric stability and surface type (Ganzeveld et al., 1998).

After accounting for dry deposition in each bin, the lognormal distribution is reconstructed. For simplicity, the modes remain log-normal with a fixed standard deviation. Hereby, aerosol mass moves from a size range with a slower deposition velocity to a size range with a faster deposition velocity. This introduces a bias that hard to avoid, but might accelarate loss by deposition.

Apart from surface deposition, the coarse mode aerosols exhibit a non-negligible fall velocity due to gravitational settling in the atmosphere. This sedimentation process is modelled by calculating 3-D fields of the fall velocities for each mode (Slinn and Slinn, 1980). Sedimentation removes preferably the larger particles, which results in smaller fall velocities for the aerosol numbers than for aerosol masses. The sedimentation process also changes the median radii of the M7 modes.

\subsubsection{Wet deposition}

Wet deposition is split in deposition from stratiform and convective precipitation. For stratiform precipitation, in-cloud scavenging and below-cloud scavenging is handled separately. Below-cloud scavenging of gases is linearly related to the surface rain flux, using a gas-to-droplet transfer coefficient based on the Reynolds and Sherwood numbers of the falling rain droplets. For aerosols, the scavenging parameterisation from Dana and Hales (1976) is used and calculated for each aerosol mode separately. In-cloud scavenging is modelled in two phases: the mass transfer of soluble gases and aerosol to the liquid phase and the formation of rain droplets (Roelofs and Lelieveld, 1995). In convective precipitation, aerosols are assumed to be removed very efficiently (similar to $\mathrm{HNO}_{3}$ ). The removal rate is modelled as a simple function that depends on the convective precipitation at the surface (Vignati et al., 2010b).

TM5 assumes well-mixed grid cells. However, the time scale of wet removal can become faster than the mixing time scale of the grid cell. Therefore, the wet-deposition yield will increase for larger grid boxes. This is a significant issue as multiple resolutions are used within the same simulation. This issue is treated pragmatically by introducing a time paramter $\tau_{\text {nomix }}$, in which the in-cloud, belowcloud and cloudless fractions of a grid cell are treated quasiindependently (Vignati et al., 2010b). This way, the wet removal in large grid cells is slowed down, reducing the resolution dependence. Applying the wet removal on a fraction of the gridbox has always been a challenge for modellers, as outlined in a study on ${ }^{210} \mathrm{~Pb}$ (Balkanski et al., 1993).

\subsubsection{Emission}

Emission data used in the model are those recommended for the AEROCOM (Dentener et al., 2006) model intercomparison studies and from the IPCC (IPCC, 2000). For biomass burning emissions, we use climatologic inventories from the global fire emission database (GFED 2) (Randerson et al., 2006; van der Werf et al., 2006) with prescribed height distribution (Dentener et al., 2006). In these data, it is predefined in which modes the aerosols are emitted. Aerosol mass emissions have an assumed lognormal distribution with a median radius $(\bar{r})$ (Table 2 ) in their inventories. This median radius is used to calculate the total emitted aerosol number with a mode-dependent standard deviation.

Ammonia is emitted mainly by domestic animals and synthetic fertilisers. Other sources of ammonia are biomass burning, the oceans, crops, human population and pets and natural soils (Bouwman et al., 1997).

Oxidised sulphur is emitted by industry, fossil fuel combustion (Cofala et al., 2005), biomass burning (Randerson et al., 2006; van der Werf et al., 2006) and volcanoes (Andres and Kasgnoc, 1998; Halmer et al., 2002). Part (2.5\%) of the sulphur is emitted directly in the particulate form $\left(\mathrm{SO}_{4}^{2-}\right)$ (Stier et al., 2005; Dentener et al., 2006). The particulate sulphate emissions from biomass burning and fossil fuel combustion are divided equally over the Aitken and accumulation mode, while industrial sulphate emissions are all in the accumulation mode (Dentener et al., 2006).

Carbonaceous compounds are emitted by fossil fuel, biofuel (Bond et al., 2004) and biomass burning (Randerson et al., 2006; van der Werf et al., 2006). These particles are only emitted in the Aitken mode. The black carbon is always emitted as insoluble particles, while $65 \%$ of the particulate organic matter (POM) is emitted in the soluble mode (Stier et al., 2005). Production of secondary organic aerosols is modelled as a direct emission. In reality, secondary organic aerosols from e.g. terpenes are involved in the formation and the early growth of new particles (Sihto et al., 2006, 2009) and they condensate on existing particles. In our model, however, these organic compounds are directly added as particulate organic matter mass in the soluble Aitken mode (Kanakidou et al., 2005). However, to avoid unrealistic situations, particles of $10 \mathrm{~nm}$ are added when there are no other emissions in the soluble aitken mode. It is assumed that the 
Table 2. Implemented aerosol emissions with the predefined M7 modes and median emission radii.

\begin{tabular}{lllll}
\hline Compound & Category & Percentage & Mode & Median radius $(\mu \mathrm{m})$ \\
\hline $\mathrm{SO}_{4}^{2-}$ & Fossil fuel (Domestic and road transport) & 50 & ais & 0.03 \\
$\mathrm{SO}_{4}^{2-}$ & Fossil fuel (Domestic and road transport) & 50 & acs & 0.075 \\
$\mathrm{SO}_{4}^{2-}$ & Biomass burning & 50 & ais & 0.03 \\
$\mathrm{SO}_{4}^{2-}$ & Biomass burning & 50 & acs & 0.075 \\
$\mathrm{SO}_{4}^{2-}$ & Industry & 100 & acs & 0.075 \\
$\mathrm{BC}$ & Fossil fuel & 100 & aii & 0.015 \\
$\mathrm{BC}$ & Biomass burning & 100 & aii & 0.04 \\
$\mathrm{POM}$ & Fossil fuel & 65 & ais & 0.015 \\
$\mathrm{POM}$ & Fossil fuel & 35 & aii & 0.015 \\
$\mathrm{POM}$ & Biomass burning & 65 & ais & 0.04 \\
$\mathrm{POM}$ & Biomass burning & 35 & aii & 0.04 \\
$\mathrm{POM}$ & Secondary organic aerosol & 100 & ais & $0.01^{*}$ \\
$\mathrm{DU}$ & Wind blown & $* *$ & aci & $* * *$ \\
$\mathrm{DU}$ & Wind blown & $* *$ & coi & $* * *$ \\
$\mathrm{SS}$ & Wind blown & $* *$ & acs & 0.08 \\
$\mathrm{SS}$ & Wind blown & $* *$ & cos & 0.63 \\
\hline
\end{tabular}

* SOA is assumed to condensate on existing aerosols so particle numbers are only created when needed to prevent unrealistic situations.

** Emissions in different modes are independent.

*** Variable radius, included in the AEROCOM emission file.

organic matter involved in nucleation has been coagulated efficiently. Furthermore, through coagulation of the Aitken mode particles, we mimic the condensation of these organic compounds to the accumulation mode.

For dust, we used pre-calculated AEROCOM data (Dentener et al., 2006). The emission sizes are variable and are pre-calculated as well. Dust is emitted both in the insoluble accumulation mode and the Insoluble coarse mode. Sea salt emissions are calculated online as function of the ten-meter wind speed as described in Vignati et al. (2010a) and Gong (2003). Sea salt is emitted in both the soluble accumulation mode and the soluble coarse mode.

\subsubsection{Aerosol optics}

We calculate the AOD in our model from the aerosol concentrations using Mie scattering theory (Mie, 1908; Barber and Hill, 1990). An aerosol contributes to the AOD, depending on its wet radius $\left(r_{\mathrm{w}}\right)$, its complex refractive index $(m)$ and the wavelength $(\lambda)$.

The size of the wet droplets $\left(r_{\mathrm{W}}\right)$ is calculated from the median wet radius $\left(\overline{r_{\mathrm{W}}}\right)$ and the fixed standard deviation $(\sigma)$. The refractive index $(m)$ of aerosol compounds, including water, are based on ECHAM-HAM (Kinne et al., 2003), OPAC (Hess et al., 1998) and Segelstein (Segelstein, 1981).

We compute for each time step, for each grid cell and for each aerosol mode an effective refractive index based on the chemical composition. We do not employ a simple volume-weighted mean of the refractive indices of the chemical compounds, which is known to give inaccurate results. Rather, we use proper effective medium theory from
Maxwell-Garnett (Maxwell-Garnett, 1904) and Bruggeman (Bruggeman, 1935).

Mie-scattering calculations demand a significant computational burden and simplifying the Mie-scattering theory causes significant errors (Boucher, 1997). To tackle this problem, we pre-calculated a lookup table. The input parameters of this lookup table (refractive index and size) are sampled with forty times fifteen values for the refractive index (real $\times$ imaginary) and a hundred values for the size parameter $\frac{\overline{r_{\mathrm{W}}}}{\lambda}$. With interpolation, the discretisation error is expected to be low (at most a few percent).

By calculating the AOD at several wavelengths, we can determine the Angström parameter (Russell et al., 2010) with the following general relationship between AOD and wavelength ( Ångström, 1929):

$\tau=\beta \lambda^{-\alpha}$

Here, $\tau$ is the AOD, $\beta$ is a prefactor, $\lambda$ is the wavelength and $\alpha$ is the Angström parameter. The prefactor $\beta$ is a measure for the overall AOD and the Ångström parameter is a measure for the wavelength-dependence of the AOD. Verification on the Ångström parameter enables to check whether the aerosol distribution is dominated by fine $(\alpha>1.3)$ or coarse $(\alpha<1.3)$ particles.

\subsection{In-situ measurements}

The modelled concentrations are compared to in-situ measurements from the EMEP network (EMEP, 2008) (http://www.emep.int), which provides data for a host of air pollutants (Lazaridis et al., 2002; EMEP, 2008). We used the 
yearly averaged data for particulate matter, aerosol composition and aerosol precursors. The averaged data for 2006 were used for the stations that produced valid data during at least $10 \%$ of the time. For the vast majority of the used data points (94\%), this valid-data percentage was above $50 \%$. Verification of the model results against measurements for PM and its components is hampered by potential artefacts in the sampling. PM filter measurements are uncertain due to potential losses of ammonium nitrate and absorption of nitric acid and organic compounds (Vecchi et al., 2009). The abovementioned volatilisation and absorption artefacts cause the sampling of nitrate and ammonium to be difficult (Yu et al., 2006; Zhang and McMurry, 1992; Cheng and Tsai, 1997). Correct sampling is only possible with denuder filter packs. However, these labour intensive methods are hardly used in Europe (Schaap et al., 2002). Hence, we use aerosol nitrate and ammonium data from inert filters, although we acknowledge that they are prone to losses at temperatures above $20^{\circ} \mathrm{C}$ (Schaap et al., 2004b). Most data on nitrate and ammonium, however, are given as the sum of gas and aerosol concentration. Gas phase concentrations for ammonia and nitric acid obtained with a filter pack are used here when reported by EMEP.

Observations of sulphur and nitrogen compounds are reported as masses $\mathrm{S}$ and $\mathrm{N}$ rather than total mass. Sea-salt concentrations are evaluated with observed sodium (Na) concentrations. Throughout this paper, we will express any sulphur compounds, nitrogren compounds or sea salt as masses $\mathrm{S}, \mathrm{N}$ and $\mathrm{Na}$. For the conversion of total sea salt to sodium, we use a conversion factor of 0.306 (Millero, 2004).

Unfortunately, measurements of carbonaceous compounds of 2006 are very scarce. Therefore, we will use measurements from the EMEP EC-OC campaign in 2002-2003 (Yttri et al., 2007). In the EMEP campaign, organic carbon (OC) is measured, while TM5 simulates organic matter (POM). In the analysis, a factor 1.4 is used to convert the observations of organic carbon to organic matter to account for the noncarbon part of the organic matter.

There are also insufficient observations of mineral dust aerosol. Mineral dust is a mixture of many components, so it is very difficult to measure it reliably, especially when only a small fraction of the total aerosol mass is dust, which is the case in the majority of Europe.

We compare the modelled aerosol optical depth (AOD) to European observations from the Aerosol Robotic Network (AERONET) (Holben et al., 2001). These are measured by the sun-powered CMEL Electrique 318A specral radiometer that points systematically to the sun in a programmed routine (http://aeronet.gsfc.nasa.gov).

In the model, the AOD is calculated at the wavelengths $(\lambda)$ at which the AERONET stations measure. We sample the observed AOD-values with 1.5-h intervals, where multiple measurements within one interval are averaged. This adapts the time resolution of the observations to that of the model.
We also analyse the ability of the model to simulate the Ångström parameter. The Ångström paramter is reported by AERONET as well. In our model, we use a function fit of Eq. (3) to obtain the Ångström parameter.

\section{Results and discussion}

In this section, we first examine the modelled surface concentrations of the aerosol components and precursor gases in Europe, as well as AOD and Ångström parameter. Next, we compare these results with observations followed by the European budget of aerosol compounds and precursors. To address the model's ability to simulate the full aerosol burden we evaluate the modelled AOD and Ångström parameter with observations. Finally, we will address two main uncertainties, namely wet removal and biomass burning emissions.

\subsection{Concentration distribution}

The annual average concentration distribution of aerosol chemical compounds and their precursors are shown in Fig. 1. The AOD and the Ångström parameter are shown in Fig. 2.

Nitrogen and sulphur oxides show a hot-spot structure with high concentrations in industrialised regions with $\mathrm{SO}_{\mathrm{x}}$ $\left(\mathrm{SO}_{2}, \mathrm{H}_{2} \mathrm{SO}_{4}\right)$ more in Eastern Europe and $\mathrm{NO}_{\mathrm{y}}\left(\mathrm{NO}, \mathrm{NO}_{2}\right.$, $\mathrm{NO}_{3}, \mathrm{HNO}_{4}, \mathrm{~N}_{2} \mathrm{O}_{5}, \mathrm{PAN}$ ) more in the Western Europe. We clearly model an ammonia hot spot in the Netherlands, which is due to high population of livestock (Buijsman et al., 1987). Nitric acid shows high concentrations over sea. In reality, nitric acid may react with sea salt and displace chloride (Glasgow, 2008; Schaap et al., 2004a). This reaction is not implemented in the model, since it has only a small effect on the aerosol distribution over land.

In contrast to primary gaseous pollutants, secondary inorganic aerosols have smoother distributions as they are of secondary origin. The ammonium concentration shows features of both nitrate, which peaks in north-western Europe and in the Po Valley, and sulphate, which shows highest concentrations in south-eastern Europe. This is because both nitric acid and sulphuric acid are neutralised by ammonium.

Primary anthropogenic carbonaceous aerosols show high concentrations in densely populated and industrialised regions. As for primary gaseous pollutants $\left(\mathrm{NO}_{\mathrm{y}}\right.$ and $\left.\mathrm{SO}_{\mathrm{x}}\right)$, this results in a hot-spot structure. For black carbon and organic matter, the hot spots are located at different positions. However, the hot spot structures of $\mathrm{NO}_{\mathrm{y}}$ and black carbon only differ slightly (more $\mathrm{NO}_{\mathrm{y}}$ in England and more black carbon in Poland).

Mineral dust shows a sharp gradient from the Sahara to the north with significant concentrations over the Mediterranean countries. North of the Alps, mineral dust concentrations are low. As expected, sea-salt concentrations are highest above 

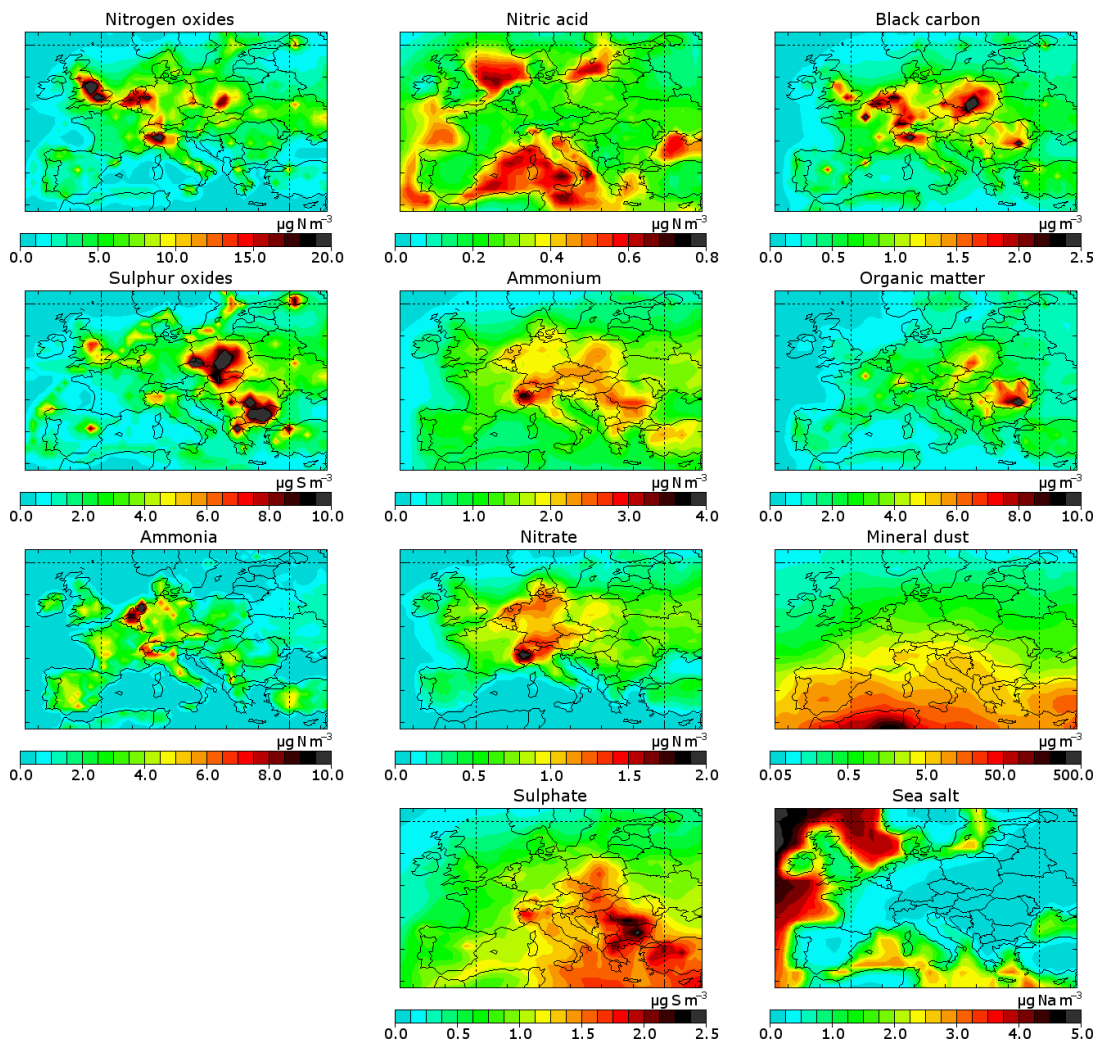

Fig. 1. Modelled surface concentrations of the aerosol tracers and precursor gases. Note that the colour scale used for mineral dust is logarithmic. Nitrogen oxides include $\mathrm{NO}, \mathrm{NO}_{2}$, Peroxyacytyl nitrate (PAN), $\mathrm{NO}_{3}, \mathrm{HNO}_{4}$ and $\mathrm{N}_{2} \mathrm{O}_{5}$, but no nitric acid or aerosol nitrate. Sulphur oxides include $\mathrm{SO}_{2}$ and $\mathrm{H}_{2} \mathrm{SO}_{4}$, but no aerosol sulphate. All values are averaged over 2006.
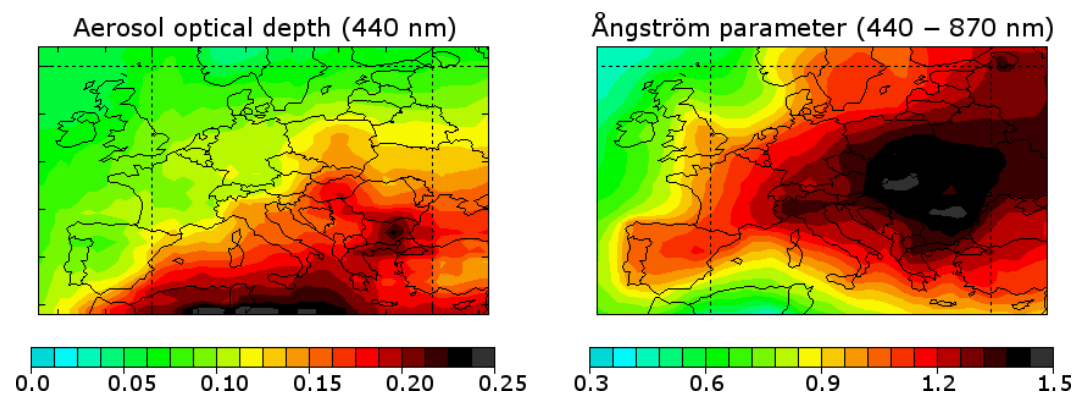

Fig. 2. Modelled optical properties of the atmospheric column averaged over 2006.

open sea. Above land, significant sea salt-concentrations are only present in coastal areas.

The calculated annual mean AOD is highest in the south and south-eastern Europe with values above 0.15. Mineral dust and sulphate appear to be the most dominant contributors to the AOD, since the AOD is high at locations where mineral dust or sulphate is abundant (see Figs. 1 and 2). The Ångström parameter is low over the sea and over northern Africa, because sea salt and desert dust are mostly coarse mode aerosols. Over land, the fine anthropogenic aerosols dominate, resulting in high Ångström parameters.

\subsection{Model evaluation}

Model results of particulate matter compounds and precursor gases have been compared with in-situ observations. When comparing with size-segregated observations (e.g. $\mathrm{PM}_{10}$ ), the log-normal distribution of M7 is used to calculate which fraction of the modelled aerosol mass is below the size limit. First, we will compare annually averaged concentrations. Later on, we will analyse a few time series of $\mathrm{PM}_{10}$ for January 2006. We chose to evaluate January, because the surface concentrations are the most senstivie to synoptic events in winter. 


\subsubsection{Annual means}

The most important results of the comparison of annually averaged aerosol and precursor concentrations are shown in Fig. 3. Figure 4 shows the results per country represented in a graphic way.

Total reduced nitrogen (ammonia and ammonium) is slightly overestimated. Aerosol ammonium is represented quite well, but ammonia is overestimated. It is well-known that modelling ammonia is challenging due to the importance of local effects (Dentener and Crutzen, 1994). Still, the Dutch ammonia hot spot is caught remarkably well in the model. Interestingly, TM5 overestimates ammonia while many other models underestimate ammonia concentrations (Schaap et al., 2004a). An issue is that the night-time concentrations estimated by the model are too high. These concentrations are very sensitive to the stability of the nocturnal boundary layer (van Loon et al., 2007). Especially TM5, as a global model, has resolution limitation for the nocturnal boundary layer, because it is a small-scale phenomenon $(\sim 50 \mathrm{~m})$. Therefore, the nocturnal boundary layer tends to be poorly defined in TM5. This is very important for ammonia, because the modelled emissions are assumed constant over the day (de Meij et al., 2006), which implies that ammonia is emitted into the stable boundary layer, causing night-time accumulation. In reality, ammonia emissions show a considerable diurnal variation with peak emissions during the day and even a net night-time surface uptake of ammonia (Wichink Kruit et al., 2007), which may be released during the next day.

The total oxidised nitrogen (nitric acid and aerosol nitrate) is represented better. There is some overestimation, but the spatial correlation is good $(r=0.89)$. When considering aerosol nitrate, about the same conclusions could be drawn. However, the modelled concentrations of nitric acid are far off (bad correlation and overestimation by a factor of two). We already addressed that the values above sea are modelled too high because the acid displacement reaction is not taken into account (see Sect. 3.1 and Schaap et al., 2004a; Glasgow, 2008). This issue may affect modelled concentrations in coastal areas, where many stations are located. Though the nitric acid concentration is the difference between total nitrate and aerosol nitrate (both well represented in the model), nitric acid has higher uncertainties because of higher uncertainties in sampling for nitric acid (see Sect. 2.3). Also, the nitric acid concentrations are often much lower than the aerosol nitrate concentrations, which means that the relative uncertainty becomes higher.

Sulphate is represented quite well. However, there is an overestimation by a factor of two for sulphur dioxide, the precursor of sulphate (not shown). A slow oxidation of sulphur dioxide may partly explain this discrepancy, but higher oxidation would also lead to higher surface sulphate concentrations. However, increased in-cloud oxidation at higher altitudes would be more consistent. The time scale of in-cloud oxidation of sulphur dioxide is very uncertain (Langner and Rodhe, 1991). Also, the emission heights of sulphur dioxide may play an important role. For instance, the sulphur dioxide emissions from AEROCOM are higher in the lower model levels than those of EMEP, which can cause a surface concentration discrepancy of a factor of two in eastern Europe (de Meij et al., 2006). Another possibility is that the emission rate of sulphur dioxide is too high in the model or there is an unaccounted or underestimated loss of sulphur dioxide that does not lead to sulphate production, e.g. dry deposition (Chin et al., 2000).

As we mentioned in Sect. 2.3, we compare our modelled results with observations from the EC-OC campaign of 2002 and 2003. Black carbon is represented well, as shown also in Vignati et al. (2010b). There is a huge (factor 3 or more) underestimation of particulate organic matter, though there is a quite okay spatial correlation between observations and model results. Secondary organic aerosols (Volkamer et al., 2006) and resuspended aerosols (Sternbeck et al., 2002), which are rich in organic matter, are significantly underestimated by TM5. An earlier evaluation of organic matter (Vignati, personal communication, 2010) also shows such an underestimation.

From the comparison of modelled and observed total particulate matter, we can conclude that the aerosol spatial distribution is reproduced reasonably well. There is a slight underestimation of the coarse aerosols $\left(\mathrm{PM}_{10}\right)$ that is probably due to resuspension of aerosols, which is not included in the model, but may be important for local $\mathrm{PM}_{10}$ concentrations (Sternbeck et al., 2002). Another factor can be an underestimation of secondary organic aerosols (Volkamer et al., 2006) or the unaccounted mass (e.g. dust or water) which is frequently present in $\mathrm{PM}_{10}$ measurements.

The spatial variability of sea salt is represented very well. However, the absolute concentrations are significantly (50\%) overestimated, probably due to uncertainties in emissions and the dry deposition parameterisation. A sea salt overestimation is also shown in Manders et al. (2010).

\subsubsection{Time series January 2006}

To evaluate the ability of TM5 to capture synoptic events, we compare time series of modelled and observed total $\mathrm{PM}_{10}$ for January 2006. Four EMEP stations provide hourly data of $\mathrm{PM}_{10}$ for this month. The results are shown in Fig. 5.

We clearly calculate less variability than observed. TM5, as a global model, is unable to simulate local effects of short durations. This is most clearly visible in Narbeth (GB) where TM5 cannot follow the rapid changes in $\mathrm{PM}_{10}$ that are observed. Vredepeel (NL) and Vavihill (SE) are represented quite well. The timing of the peaks is roughly correct. Only the magnitudes of two peaks are significantly underestimated, namely the Vredepeel (NL) peak around day 27 and the Vavihill (SE) peak around day 15. TM5 is clearly unable to simulate aerosol concentrations on Ayia Marina (CY). 

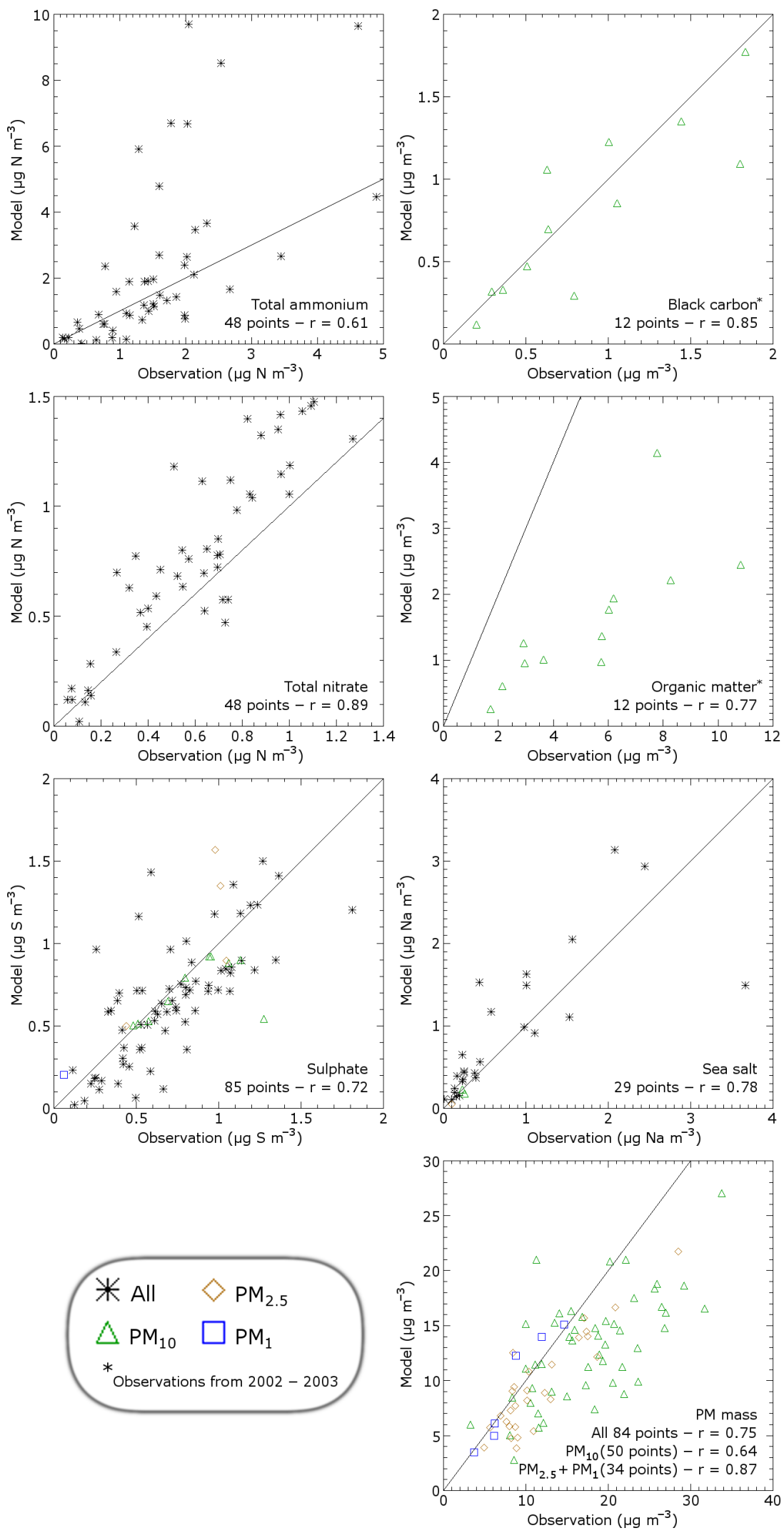

Fig. 3. Comparison between modelled and observed average concentrations over 2006 for total ammonium, total nitrate, sulphate, black carbon, organic matter, sea salt and total particulate matter at EMEP ground stations. The colours and shapes indicate the aerosol size class. 

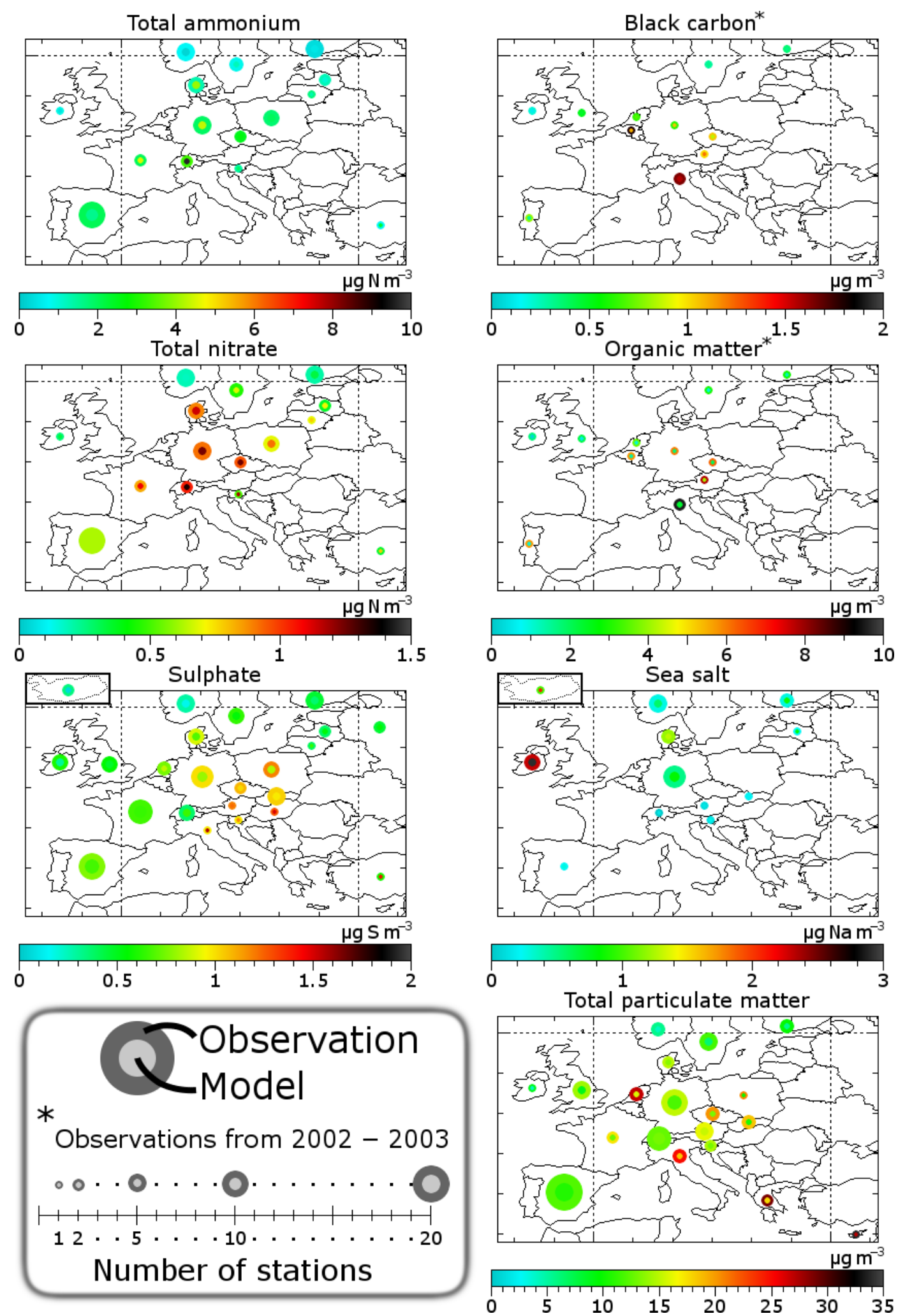

Fig. 4. Graphical overview of the comparison between modelled and observed average concentrations over 2006 for total ammonium, total nitrate, sulphate, black carbon, organic matter, sea salt and total particulate matter at EMEP ground stations. Values of stations per country are averaged. The size of the circles represent the number of stations in that country. The country in the upper left box of the sulphate and sea salt maps, is Iceland. 
Table 3. European annual budget table of nine tracers for the boundary layer (surface up to $850 \mathrm{hPa}$ ), with (B)urden, (L)ifetime; the sinks: (C)hemical reactions, (A)erosol condensation, (D)ry deposition, (W)et deposition, $(\mathrm{H})$ orizontal transport and (V)ertical transport; and the sources: (E)mission, (C)hemical reactions, (A)erosol condensation, (H)orizontal transport and (V)ertical transport. Burdens (Gg) are averages of monthly samples. Lifetimes (days) are burdens divided by total sinks. Fluxes $\left(\mathrm{Gg} \mathrm{yr}^{-1}\right)$ are annual totals. $\mathrm{NO}_{\mathrm{y}}$ includes $\mathrm{NO}$, $\mathrm{NO}_{2}$, Peroxyacytyl nitrate (PAN), $\mathrm{NO}_{3}, \mathrm{HNO}_{4}$ and $\mathrm{N}_{2} \mathrm{O}_{5}$, but no nitric acid or aerosol nitrate. $\mathrm{SO}_{\mathrm{x}}$ includes $\mathrm{SO}_{2}$ and $\mathrm{H}_{2} \mathrm{SO}_{4}$, but no aerosol sulphate. Nitrogen compounds are expressed as masses $\mathrm{N}$, sulphur compounds as masses $\mathrm{S}$ and sea salt as masses $\mathrm{Na}$.

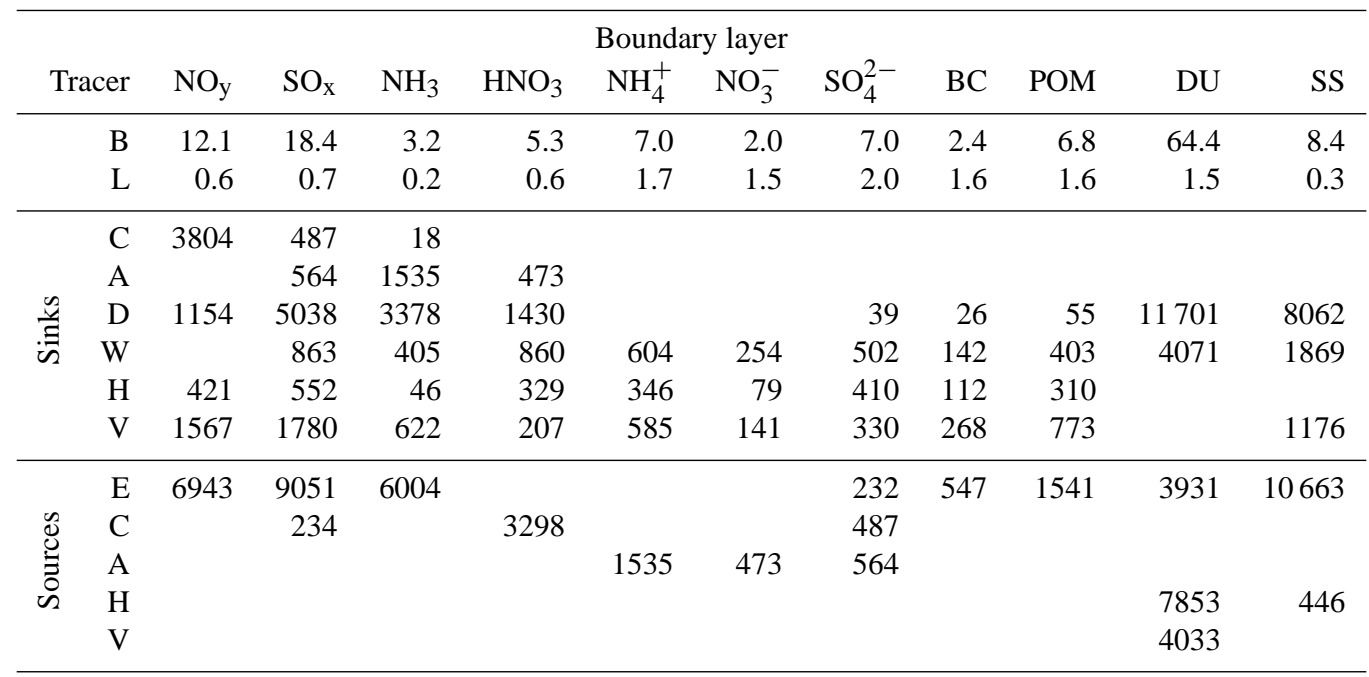

Here, resolution plays a big role, because Cyprus is an island as small as a TM5 grid box. Therefore, TM5 models dust storms at Ayia Marina (CY) that are not observed at the station. Only the broad peak at the beginning is visible in the observations, though with a much smaller magnitude.

\subsection{The aerosol budget}

For the analysis of the aerosol budget, we split the atmosphere over Europe into two parts: the boundary layer (surface up to $850 \mathrm{hPa}$ ) and the free atmosphere $(850 \mathrm{hPa}$ up to top of atmosphere). The budget is split into sources and sinks and the processes: emission (E), chemical reactions $(\mathrm{C})$, aerosol condensation (A), dry deposition (D), wet deposition $(\mathrm{W})$ and the horizontal $(\mathrm{H})$ and vertical $(\mathrm{V})$ transport terms. The vertical transport term denotes the transport of tracer mass between the boundary layer and the free troposphere. Nitric acid also has a stratospheric boundary condition determined by its relationship with stratospheric ozone (Santee et al., 1995). The gain or loss due to this boundary condition is counted as vertical transport $(\mathrm{V})$ for the free atmosphere.

Figure 6 visualises the transport terms and all budget terms are listed in Tables 3 and 4 . Note that the lifetimes, especially in the boundary layer, are low because export terms, including vertical export, are regarded as sinks as well. All budgets close with an accumulation or depletion (difference between sources and sinks) of less than one percent of the budget.

Although only $15 \%$ of the air mass is in the boundary layer, the calculated burdens in the boundary layer are com- parable to those in the free atmosphere. However, the horizontal fluxes in the boundary layer are much smaller than in the free atmosphere (see Fig. 6), indicating that the boundary layer budget is dominated by emission, deposition and vertical transport. Wet deposition is the major sink of all aerosols, except for mineral dust and sea salt, which exhibit efficient dry deposition because of their large size (see Tables 3 and 4). The numbers in these tables are raw model results, only rounded to whole gigagrams per year, while the uncertainties are much larger. Given the uncertainties, we will round percentages in the interpretations to multiples of $5 \%$.

We model a net export of all anthropogenic aerosol compounds from Europe and a net import of natural aerosol (sea salt and mineral dust). The boundary layer over Europe exports anthropogenic aerosols in all four directions, while in the free atmosphere, Europe imports aerosols and gases from the west due to the jet stream. However, the net horizontal export in the free atmosphere is comparable to the export in the boundary layer as a large part of the tracers in the jet stream are not deposited in Europe but pass through the European domain.

Out of the emitted carbonaceous compounds (BC and POM), about $50 \%$ reaches the free atmosphere and $20 \%$ is exported in the boundary layer. The other $30 \%$ is removed, mainly by wet deposition. Dry deposition plays only a limited role (less than $5 \%$ of emission). The carbonaceous compounds that reach the free atmosphere are removed partially $(65 \%)$ in clouds (wet removal). The rest is exported out of the domain. Note that biomass burning can 
Table 4. European annual budget table of nine tracers for the free atmosphere ( $850 \mathrm{hPa}$ up to top of atmosphere), with (B)urden, (L)ifetime; the sinks: (C)hemical reactions, (A)erosol condensation, (D)ry deposition, (W)et deposition, (H)orizontal transport and (V)ertical transport; and the sources: (E)mission, (C)hemical reactions, (A)erosol condensation, (H)orizontal transport and (V)ertical transport. Vertical transport includes stratospheric interchange. A value of 0 in the table means a value below 0.5 (rounded down to 0 ), while an empty spot means that the process does not take place at all. Burdens $(\mathrm{Gg})$ are averages of monthly samples. Lifetimes (days) are burdens divided by total sinks. Fluxes $\left(\mathrm{Gg} \mathrm{yr}^{-1}\right)$ are annual totals. $\mathrm{NO}_{\mathrm{y}}$ includes $\mathrm{NO}, \mathrm{NO}_{2}$, Peroxyacytyl nitrate $(\mathrm{PAN}), \mathrm{NO}_{3}, \mathrm{HNO}_{4}$ and $\mathrm{N}_{2} \mathrm{O}_{5}$, but no nitric acid or aerosol nitrate. $\mathrm{SO}_{\mathrm{x}}$ includes $\mathrm{SO}_{2}$ and $\mathrm{H}_{2} \mathrm{SO}_{4}$, but no aerosol sulphate. Nitrogen compounds are expressed as masses $\mathrm{N}$, sulphur compounds as masses $\mathrm{S}$ and sea salt as masses $\mathrm{Na}$.

\begin{tabular}{|c|c|c|c|c|c|c|c|c|c|c|c|c|}
\hline \multicolumn{13}{|c|}{ Free atmosphere } \\
\hline \multicolumn{2}{|c|}{ Tracer } & $\mathrm{NO}_{\mathrm{y}}$ & $\mathrm{SO}_{\mathrm{x}}$ & $\mathrm{NH}_{3}$ & $\mathrm{HNO}_{3}$ & $\mathrm{NH}_{4}^{+}$ & $\mathrm{NO}_{3}^{-}$ & $\mathrm{SO}_{4}^{2-}$ & $\mathrm{BC}$ & $\mathrm{POM}$ & DU & SS \\
\hline & B & 38.5 & 16.9 & 0.6 & 21.3 & 7.5 & 0.6 & 13.8 & 2.1 & 8.7 & 339.4 & 10.7 \\
\hline & $\mathrm{L}$ & 7.6 & 1.5 & 0.4 & 5.8 & 2.5 & 1.6 & 2.9 & 2.9 & 4.0 & 6.1 & 2.0 \\
\hline \multirow{6}{*}{$\begin{array}{l}\tilde{n} \\
\tilde{n}\end{array}$} & $\mathrm{C}$ & 1384 & 878 & 6 & & & & & & & & \\
\hline & A & & 555 & 496 & 6 & & & & & & & \\
\hline & D & & & & & & & & & & & \\
\hline & W & & 864 & 101 & 850 & 576 & 90 & 984 & 149 & 536 & 16161 & 1926 \\
\hline & $\mathrm{H}$ & 454 & 1908 & 20 & 488 & 505 & 59 & 778 & 121 & 259 & & \\
\hline & V & & & & & & & & & & 4033 & \\
\hline \multirow{5}{*}{ 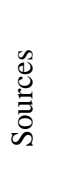 } & E & 275 & 2320 & & & & & 0 & 2 & 20 & & \\
\hline & $\mathrm{C}$ & & 102 & & 1119 & & & 878 & & & \multirow{4}{*}{20179} & \\
\hline & A & & & & & 496 & 6 & 555 & & & & \\
\hline & $\mathrm{H}$ & & & & & & & & & & & 754 \\
\hline & V & 1567 & 1780 & 622 & 222 & 585 & 141 & 330 & 268 & 773 & & 1176 \\
\hline
\end{tabular}

inject non-negligable amounts of carbonaceous components into the free atmosphere (Dentener et al., 2006).

Mineral dust is the only component that has a net negative vertical flux in Europe, from the free atmosphere to the boundary layer. Figure 6 shows that the major transport pathway of dust lies in the free troposphere. Table 3 shows that the emission term for dust in the defined European domain is relatively small compared to the transport term. These features for mineral dust are in line with common understanding that during sand storms mineral dust is transported to elevated altitudes by strong convection. Outflow and transport towards Europe occurs above a marine boundary layer causing import at higher altitudes. Sea salt does not exhibit these features as a big part of its emission source (open sea) is within the budget regeion. Therefore, it has a net positive vertical flux, like the anthropogenic tracers.

About $25 \%$ of the emitted ammonia is absorbed by aerosols in the boundary layer. Only $10 \%$ reaches the free atmosphere, of which most (80\%) gets absorbed by aerosols there. Notable is that, in contrast to aerosols, ammonia is removed much more by dry deposition (55\% of emission) than by wet deposition (5\% of emission). Transport of ammonia out of Europe is negligible.

About $15 \%$ of the nitric acid produced by chemistry is taken up by aerosols. Like for ammonia, dry deposition ( $45 \%$ of production) is a larger sink for nitric acid than wet deposition (25\%). Export of nitric acid is small (10\% of production). Only about $5 \%$ of the nitric acid produced in the boundary layer enters the free atmosphere, while a sizable amount of nitric acid is produced in the free atmosphere. In this atmospheric domain, there is remarkably little absorption of nitric acid by aerosols, which is due to the acidic aerosol environment. We clearly model a high sulphate burden in the free atmosphere compared to ammonium and ammonia (see Table 4). About 35\% of the nitric acid is exported and the other $65 \%$ is removed by wet deposition.

The budget terms of the inorganic secondary aerosols (ammonium, nitrate and sulphate) are relatively similar. Almost half of the inorganic aerosol material absorbed or produced in the boundary layer is removed by wet deposotion (ammonium: $40 \%$, nitrate: $55 \%$, sulphate: $40 \%$ ). Horizontal export in the boundary layer is close to one quarter (ammonium: $25 \%$, nitrate: $15 \%$, sulphate: $30 \%$ ). The rest, about a third, enters the free troposphere (ammonium: 40\%, nitrate: 30\%, sulphate: $25 \%$ ). In the free troposphere, a little over half is removed by wet deposition (ammonium: 55\%, nitrate: $60 \%$, sulphate: 55\%) and the rest is exported. Aerosol nitrate is more concentrated in the boundary layer, while ammonium is equally distributed between boundary layer and free atmosphere and sulphate is more abundant in the free atmosphere. This can be explained by production in the free atmosphere, which is done efficiently for sulphate in clouds (60\% of production in the free atmosphere). Together with dry oxidation followed by condensation, the production of sulphate is responsible for the majority of the sulphate source in the free atmosphere $(80 \%)$, so only a small part comes from the 

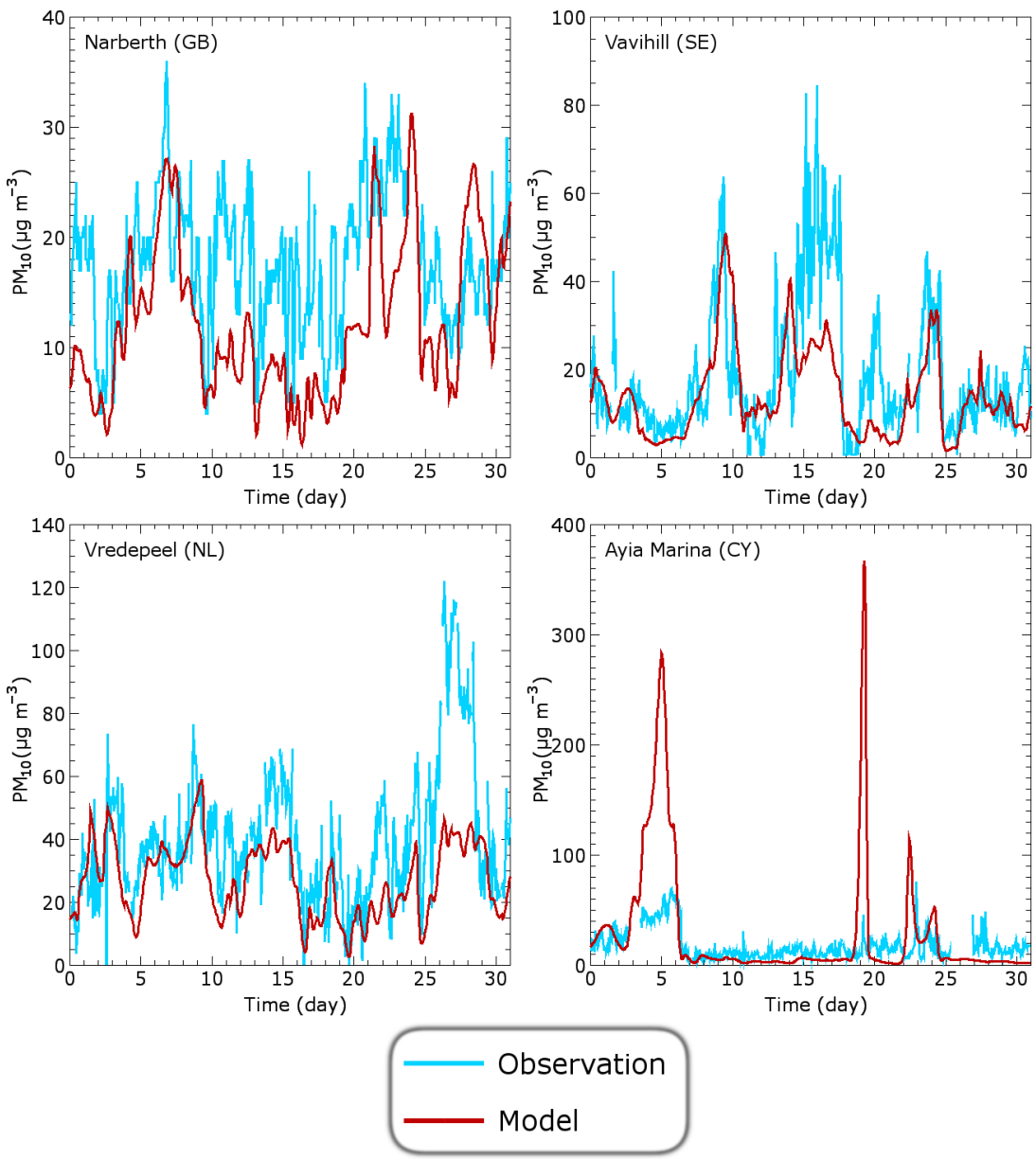

Fig. 5. Comparison between modelled and observed $\mathrm{PM}_{10}$ concentrations in January 2006 for Narberth (GB), Vredepeel (NL), Vavihill (SE) and Ayia Marina (CY).

boundary layer. For ammonium, this production percentage is $45 \%$ and for nitrate only $5 \%$. This low nitrate production in the free atmosphere is, as explained above, due to the acidic environment. Notable is that ammonium does have a significant horizontal export term (25\% in boundary layer and $50 \%$ in free atmosphere), while ammonia has not. Ammonia is only abundant in the Netherlands and only a very small part will make it to the European borders without being absorbed by aerosols.

Sulphate is produced by oxidation of sulphur dioxide, partly in clouds (45\% in boundary layer and $60 \%$ in free atmosphere). The sulphur dioxide oxidised in clouds directly produces sulphate in the aerosol phase ("C" as sulphate source and $\mathrm{SO}_{\mathrm{x}}$ sink in Tables 3 and 4), while the dry oxidation of sulphur dioxide produces sulphuric acid, which quickly condenses on aerosols ("A" as sulphate source and $\mathrm{SO}_{\mathrm{x}}$ sink in Tables 3 and 4). Out of the emitted sulphur dioxide in the boundary layer, about $10 \%$ is oxidised and another $5 \%$ is exported and $20 \%$ enters the free atmosphere. The rest is removed by dry (55\% of emission) and wet (10\% of emission) deposition. There is a considerable amount of sulphur dioxide that is injected directly into the free atmosphere, mainly by volcanic emissions (Andres and Kasgnoc, 1998; Halmer et al., 2002). Together with what is transported up from the boundary layer, this sulphur dioxide is oxidesed to sulphate for $35 \%, 20 \%$ is removed by wet deposition and $45 \%$ is exported out of Europe. Sulphur dioxide production by oxidation of dimethyl sulphide ("C" as $\mathrm{SO}_{\mathrm{x}}$ source in Tables 3 and 4) is small.

Nitric acid, and thus aerosol nitrate, originates from other nitrogen oxides in the atmosphere $\left(\mathrm{NO}_{\mathrm{y}}\right)$. Note that $\mathrm{NO}_{\mathrm{y}}$ does not include nitric acid. Out of the emitted nitrogen oxides in the boundary layer, $55 \%$ is removed by chemical processes. Besides oxidation to nitric acid, nitrogen oxides are also removed by reactions with organic chemicals (not shown). Dry deposition removes $15 \%$ of the emitted nitrogen oxides in the boundary layer, $20 \%$ goes to the free atmosphere and only $5 \%$ is exported. A small amount of nitrogen oxides are directly injected into the free atmosphere by lightning (Pickering et al., 1998) and aircraft emissions. In 


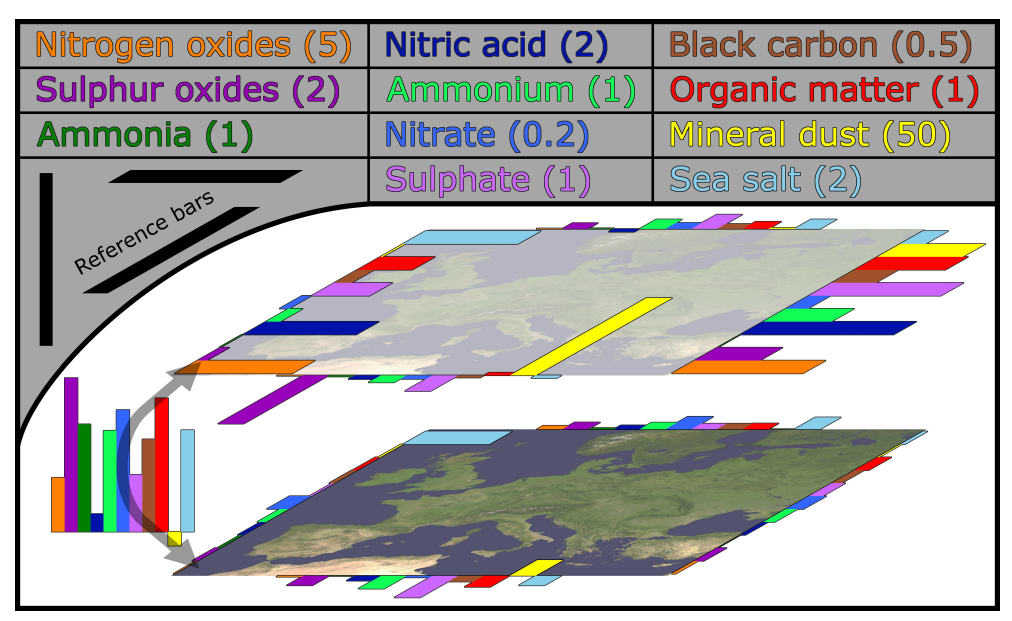

Fig. 6. Transport diagram showing fluxes from north, east, south and west for the boundary layer and the free atmosphere; and the exchange between the two layers. These values are net fluxes integrated over the year 2006. The legend at the top maps the colours to the tracers

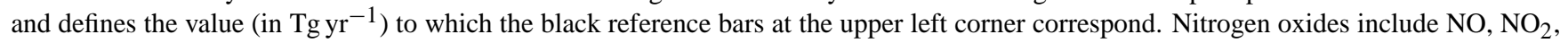
Peroxyacytyl nitrate (PAN), $\mathrm{NO}_{3}, \mathrm{HNO}_{4}$ and $\mathrm{N}_{2} \mathrm{O}_{5}$, but no nitric acid or aerosol nitrate. Sulphur oxides include $\mathrm{SO}_{2}$ and $\mathrm{H}_{2} \mathrm{SO}_{4}$, but no aerosol sulphate. Nitrogen compounds are expressed as masses N, sulphur compounds as masses $\mathrm{S}$ and sea salt as masses Na. For blackand-white print: the bars represent from left to right (for east/west transport from bottom to top): nitrogen oxides, sulphur oxides, ammonia, nitric acid, ammonium, nitrate, sulphate, black carbon, organic matter, mineral dust and sea salt.
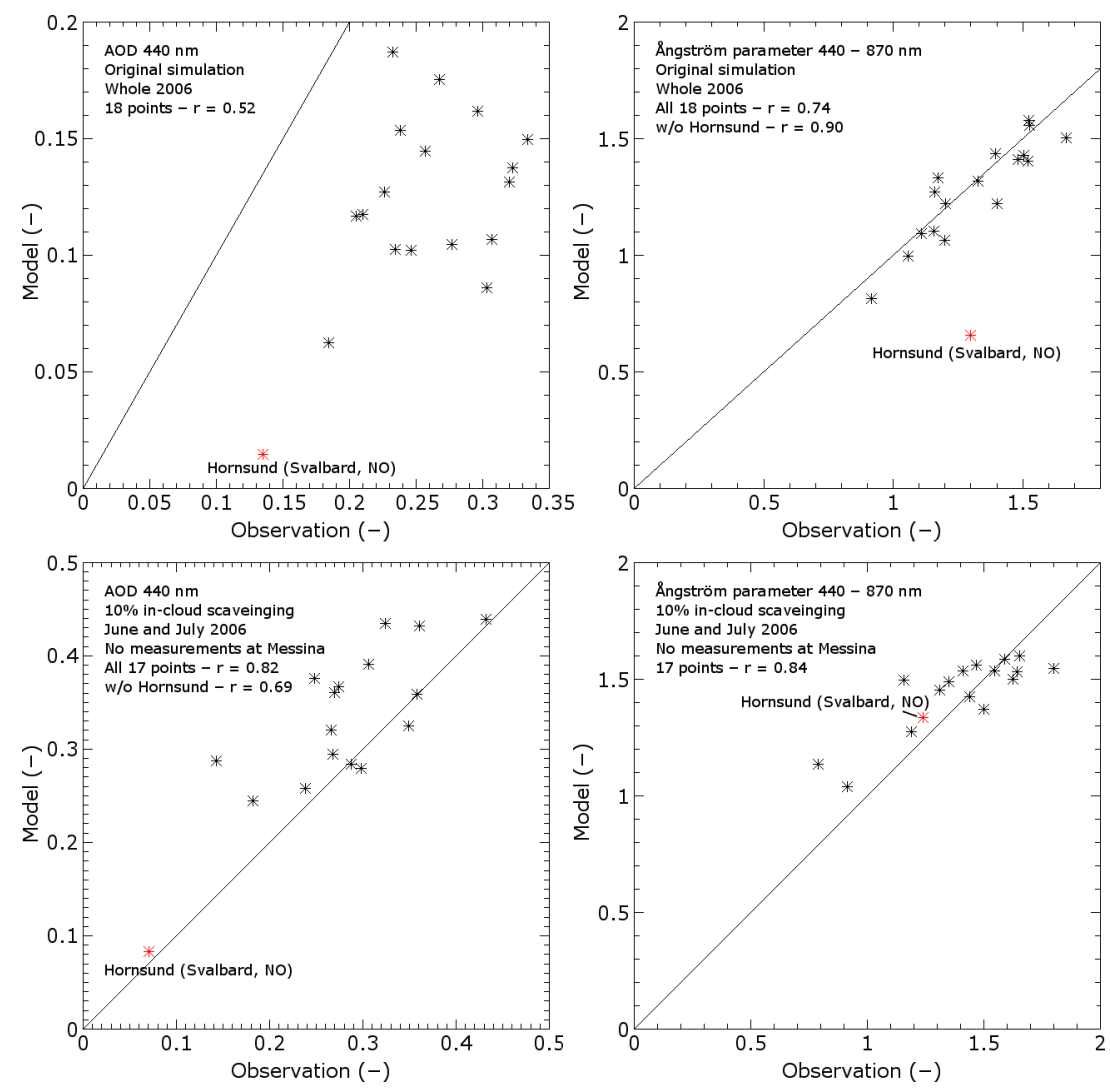

Fig. 7. Comparison between modelled and observed AOD (440 nm) and Ångström parameter (440-870 nm) at AERONET stations. Above: Original results (average over whole 2006). Below: simulation with in-cloud scavenging rates scaled down by a factor of 10 (average over June and July 2006). 

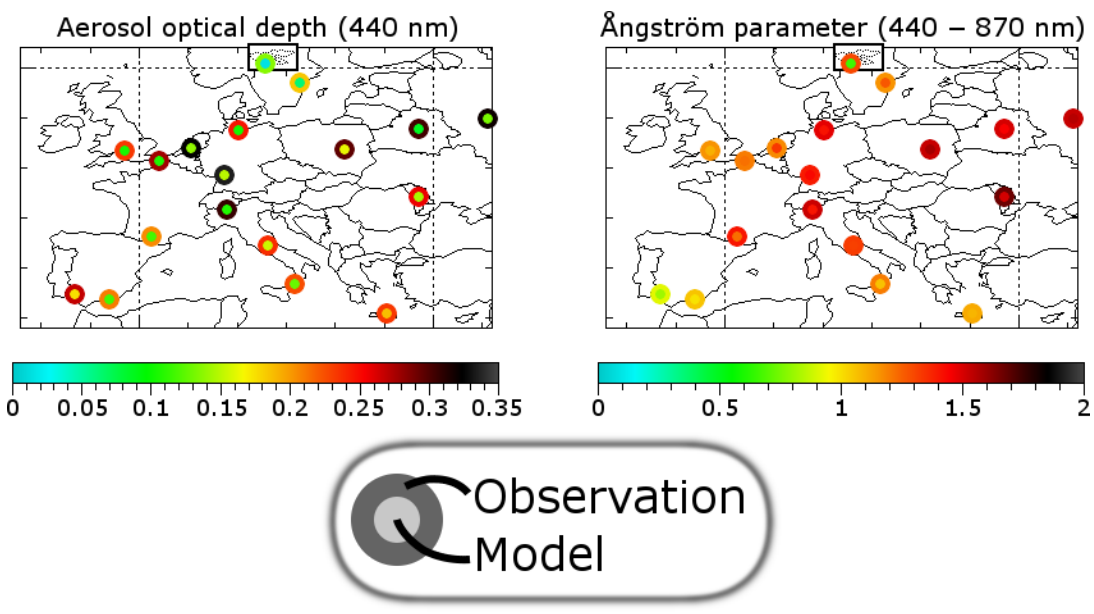

Fig. 8. Graphical overview of the comparison between modelled and observed AOD (440 nm) and Ångström parameter (440-870 nm) at AERONET stations. The island in the upper box is Svalbard (Norway).

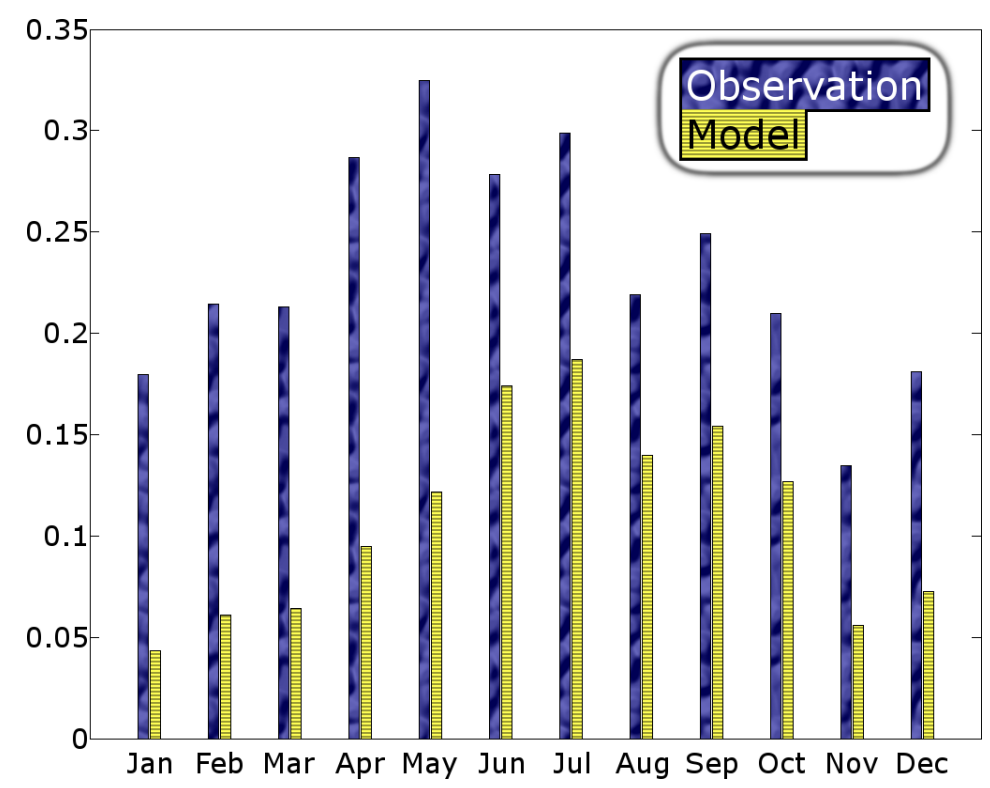

Fig. 9. Comparison between modelled and observed AOD per month. Valid data of all AERONET stations are averaged.

the free atmosphere, $75 \%$ of the nitrogen oxides is removed chemically and $25 \%$ is exported.

\subsection{Optical analysis}

In Table 5, Fig. 7 (upper panels) and Fig. 8, we compare the calculated optical data with AERONET observations. We clearly underestimeate AOD systematically, though the temporal variability is captured adequately by the model. Generally, the AOD in summer is much higher than in winter, and the relative underprediction by TM5 is less in summer and early autumn (factor less than two) than in other months with a factor often above two (see Fig. 9). Also note that more data points are available in summer than in winter.
As the AOD is severely underestimated, we can conclude that besides the small underestimation of the $\mathrm{PM}_{10}$ surface concentrations, the total column burden appears to be underestimated by a factor of two. Part of the underestimation may be due to emissions that are not included in the model. de Meij et al. (2006) shows that calculated AODs at low relative humidities are underestimated, indicating that the AEROCOM emissions are too low. Another reason for the underestimation of the AODs is that the vertical distribution is not well represented. The underestimated emissions include non-combustion aerosols such as emissions from agricultural activities or traffic abrasion and resuspension (Sternbeck et al., 2002). However, this will mainly 

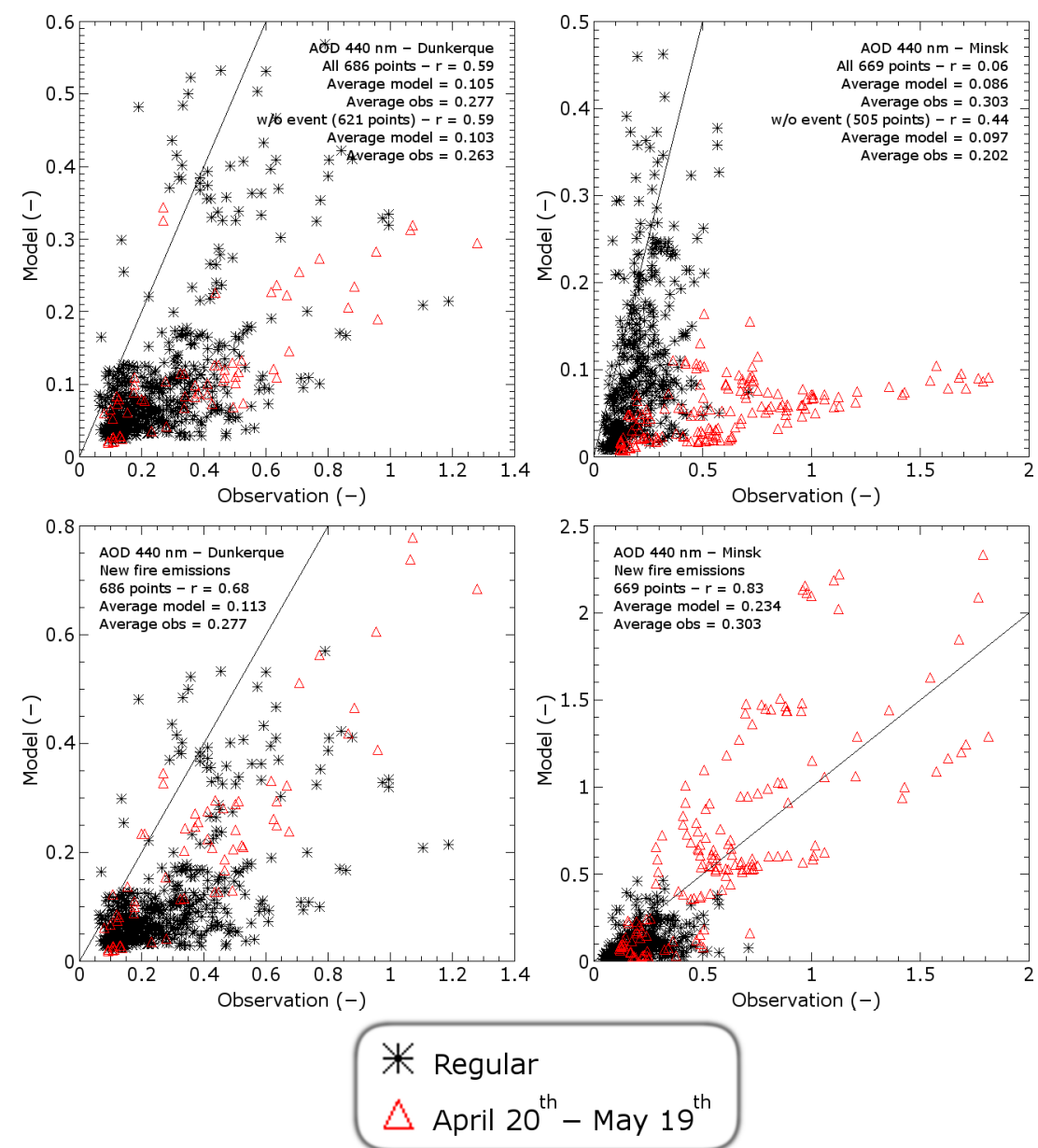

Fig. 10. Time series of modelled and observed AOD $(440 \mathrm{~nm})$ for Dunkerque (left) and Minsk (right). Upper panels: Only climatologic GFED emissions. Lower panels: New simulation with FAS-SILAM emissions. Both simulations use the regular wet-deposition rates.

affect surface $\mathrm{PM}_{10}$ concentrations rather than AOD. We will show in Sect. 3.5.2 that the severe underestimation of the AOD in eastern Europe is largely explained by inadequate biomass burning emission used by the model. The underestimation of the AOD may also be related to too high wetdeposition rates (Chin et al., 2000). Wet deposition is a dominant term in the budget (Tables 3 and 4) and we will address this further in Sect. 3.5.1.

At those stations that are located within or near major source regions of black carbon, part of the underestimation of AOD values may derive from biases introduced by the homogeneous sphere approximation, which is employed in Mie computations. For instance, externally mixed black carbon aggregates absorb twice as much radiation in the atmosphere as volume-equivalent homogeneous spheres (Kahnert, 2010a,b). Model computations that account for inhomogeneous mixing of $\mathrm{BC}$ with soluble aerosol components predict absorption cross sections that are a factor of 1.5 higher than those computed with a homogeneous mixture approximation (Bond et al., 2006). Such morphological effects are neglected in our effective medium and Mie computations and may contribute to the AOD bias.

There is a reasonable temporal correlations between observed and modelled Ångström parameter (Table 5). The yearly averages agree very well. Also, the spatial variability among station is represented very well. There is one exception (Hornsund, Svalbard), which is due to the low AOD values there, making the Ångström parameter very sensitive to errors.

\subsection{Uncertainty analysis}

In this section, we will investigate the uncertainties related to two key processes: wet removal and emission strengths. With sensitivity simulations we explore possible explanations for the underestimation of the AOD.

\subsubsection{Wet deposition}

Wet deposition is an important sink, especially in the free atmosphere (see Table 4). A too fast wet-deposition rate may 
Table 5. Comparison between modelled and observed optical parameters. Listed are temporal correlations and averages of time series of the AOD $440 \mathrm{~nm}$ and the Ångström parameter 440-870 nm at 18 European AERONET stations.

\begin{tabular}{lccccccr}
\hline & \multicolumn{3}{c}{ AOD 440 nm } & \multicolumn{3}{c}{ Angström 440-870 nm } & \\
Station name & temp. $r$ & model & obs. & temp. $r$ & model & obs. & \# points \\
\hline Belsk & 0.37 & 0.162 & 0.296 & 0.47 & 1.577 & 1.524 & 992 \\
Cabauw & 0.58 & 0.138 & 0.323 & 0.71 & 1.332 & 1.173 & 515 \\
Chilbolton & 0.68 & 0.103 & 0.235 & 0.58 & 1.102 & 1.156 & 746 \\
Dunkerque & 0.59 & 0.105 & 0.277 & 0.52 & 1.221 & 1.202 & 686 \\
El Arenosillo & 0.78 & 0.175 & 0.268 & 0.70 & 0.813 & 0.915 & 62 \\
Forth Crete & 0.58 & 0.187 & 0.233 & 0.72 & 1.092 & 1.108 & 1787 \\
Granada & 0.61 & 0.117 & 0.210 & 0.39 & 0.997 & 1.057 & 1733 \\
Hamburg & 0.38 & 0.102 & 0.246 & 0.27 & 1.410 & 1.481 & 843 \\
Hornsund & 0.51 & 0.015 & 0.135 & 0.45 & 0.657 & 1.298 & 265 \\
Ispra & 0.49 & 0.107 & 0.307 & 0.30 & 1.403 & 1.520 & 1280 \\
Karlsruhe & 0.60 & 0.149 & 0.334 & 0.57 & 1.435 & 1.394 & 623 \\
La Fauga & 0.61 & 0.117 & 0.205 & 0.55 & 1.222 & 1.403 & 1275 \\
Messina & 0.40 & 0.127 & 0.226 & 0.47 & 1.063 & 1.198 & 784 \\
Minsk & 0.06 & 0.086 & 0.303 & 0.61 & 1.429 & 1.505 & 669 \\
Moldova & 0.38 & 0.144 & 0.257 & 0.53 & 1.504 & 1.668 & 1302 \\
Moscow MSU MO & 0.29 & 0.132 & 0.320 & 0.48 & 1.555 & 1.528 & 772 \\
Rome Tor Vergata & 0.63 & 0.154 & 0.238 & 0.60 & 1.317 & 1.326 & 1679 \\
SMHI & 0.66 & 0.062 & 0.184 & 0.60 & 1.270 & 1.160 & 700 \\
\hline
\end{tabular}

therefore explain why the AOD is underestimated while the surface concentrations look reasonable. We performed three additional simulations for May, June and July 2006 with all in-cloud scavenging rates (both for stratiform and convective precipitation) scaled down to respectively $50 \%, 10 \%$ and $0 \%$. It appeared that halving $(50 \%)$ the in-cloud scavenging hardly made any difference in the simulated AOD values (about 10\% higher AOD after spin-up). This clearly indicates the high efficiency of wet deposition in TM5. As expected, completely ignoring it $(0 \%)$ resulted in unrealistically high values for the AOD (factor 6 after three months and ever rising). We will analyse the $10 \%$ wet-removal simulation, which showed a clear improvement, for the analysis period June and July 2006.

Figure 7 (lower panels) shows that in the $10 \%$ simulation, the large underestimation of the AOD has been turned into a slight overestimation. The Ångström parameter is still represented quite well, which indicates that the aerosol size distribution is little affected. Although the modelled AOD and Ångström parameter now agree in Hornsund, the temporal correlation between model and observations at that station remains very poor (not shown). In general, the temporal correlations remain roughly similar (not shown).

We also investigated the changes in surface concentrations that result from a reduction of in-cloud scavenging to $10 \%$. Sulphate and sea salt concentrations rise significantly (about $50 \%$ ), while other compounds change only very little. From Fig. 3, it is clear that we already overestimate sea salt by $50 \%$. Also the agreement of surface concentrations of sul- phate, good in the unperturbed simulation as shown in Fig. 3, slightly deteriorates by reducing the wet-removal rates.

It appears that a scaling factor of $10 \%$ on the wetdeposition rates results in slightly too high surface concentrations and AOD values. For AOD, we expect a slight underestimation because of non-implemented emissions of biogenic volatile compounds and resuspension. The signal of the surface concentrations also indicates that with a $10 \%$ scaling of the in-cloud scavenging, the wet removal is underestimated. The aerosol budget changes mainly in the free troposphere. Based on an analysis of the months June and July, we estimate that the wet-deposition flux is roughly halved in favour of the net export.

We refrain from a further tuning of the wet deposition here, because a sound parameterisation should be based on the physical and numerical considerations (e.g. grid-size dependency) that are associated with both stratiform and convective wet removal. We have shown, however, that a poor representation of wet deposition may be a major cause of the general underestimation of the AOD and may have masked other model deficiencies.

\subsubsection{Forest fires}

Emission inventories exhibit multiple uncertainties. We already addressed the lack of resuspension in our model and the possible underestimation of secondary organic aerosols. Besides these missed sources, there is also a significant uncertainty in biomass burning emissions. Our model uses climatologic GFED fire emissions, while real biomass burning 
emissions tend to exhibit large variability between the years and between the seasons in a year (van der Werf et al., 2006). An extreme case occurred in spring 2006, when there were strong forest fires in western Russia (Sofiev et al., 2009; Saarikoski et al., 2007). These events take place every spring, but in 2006 they were particularly strong. Apart from that, the last week of April and the first week of May, the mean wind direction in eastern Europe $\left(20^{\circ} \mathrm{E}-30^{\circ} \mathrm{E}\right)$ was easterly, which coincides with the fires. This transported the smoke towards Europe, so that it was recorded in the time series of the AOD in eastern European stations.

Figure 10 (upper two graphs) shows a comparison between modelled and observed AOD for Dunkerque and Minsk, in which we can see that Minsk exhibits a clearly separate population of points that belong to the period of the forest fires. For Dunkerque, the points of this period are more mixed with the rest of the dataset. The high observed AOD values during the event were not reproduced by the model. Because easterly circulation is associated with fair weather, the possible too high wet-deposition rates in the model is not likely to play a significant role.

To reproduce the high AOD values at the eastern European stations, we repeated the simulation with the European emission data from the Fire Assimilation System (FAS) that was used in combination with the dispersion model SILAM (Sofiev et al., 2009). The FAS-SILAM PM 2.5 emissions in the area specified below are $4.3 \mathrm{Tg}$ for the considered monthly period, while the climatologic GFED emissions in that area were only $8.7 \mathrm{Gg}$ per month (500 times less). Moreover, the GFED emissions are temporally spread over the entire months, while FAS reported them with daily resolution. As the majority of the emissions occurred during the days with easterly winds, it was evidently important to apply a daily time resolution of emissions to capture the specific transport conditions during the event.

The FAS-SILAM emission data consist of daily 2D fields of $\mathrm{PM}_{2.5}$ emissions in Europe $\left(11^{\circ} \mathrm{W}-73^{\circ} \mathrm{E}, 34^{\circ} \mathrm{N}-80^{\circ} \mathrm{N}\right)$. We assumed that $10 \%$ of this $\mathrm{PM}_{2.5}$ is black carbon and $90 \%$ is organic matter, which is a rough estimation based on observations in Saarikoski et al. (2007). This assumption may influence the results as the optical properties of black carbon and organic matter are different. Also, the injection height of these emissions can be important (Chen et al., 2009). We assumed the following distribution injection heights following Dentener et al. (2006): $20 \%$ between surface and $100 \mathrm{~m}, 20 \%$ between $100 \mathrm{~m}$ and $500 \mathrm{~m}, 20 \%$ between $500 \mathrm{~m}$ and $1 \mathrm{~km}$ and $40 \%$ between $1 \mathrm{~km}$ and $2 \mathrm{~km}$. We performed a simulation, replacing the original climatologic emissions from 15 April to 14 May.

Figure 10 (lower two graphs) show the results for the two AERONET stations. There is a drastic improvement for Minsk, which indicates that this event is caught by the model including these emissions. There is also a small improvement in the results for Dunkerque as well, which means that Dunkerque is affected by these emissions through long range transport. The improvement in the model results clearly illustrates that episodic fire events at the eastern edge of $\mathrm{Eu}-$ rope in combination with certain transport patterns may have a significant impact throughout the European domain.

\section{Conclusions}

Size-resolved aerosol simulations with the TM5 model coupled to the M7 module have been conducted for the year 2006 with a focus on the European domain $\left(34^{\circ} \mathrm{N}-62^{\circ} \mathrm{N}, 12^{\circ} \mathrm{W}-\right.$ $36^{\circ} \mathrm{E}$ ). The main conclusions can be summarised as follows:

- Comparison of the simulated aerosol distribution with surface observations over Europe shows a reasonably good agreement with spatial correlations of simulated PM mass of 0.75. As expected, spatial correlations are lowest $(r=0.64)$ and biases are highest for $\mathrm{PM}_{10}$, possibly due to neglected resuspension of aerosols. Total ammonium $(r=0.61)$ is overestimated in the high concentration range, due to the overestimation of $\mathrm{NH}_{3}$ in emission regions.

- A three-dimensional budget analysis is carried out to enable model intercomparison and assessement of important uncertainties. From our budget, we can conclude that Europe is a net exporter of anthropogenic aerosols, and an importer of natural aerosols (sea salt and mineral dust). For instance, it is calculated that about half of the emitted anthropogenic carbonaceous aerosols are exported from Europe. Dust is the only aerosol component that exhibits a negative vertical flux over the European domain. Notable is that the export rate of gaseous pollutants (e.g. nitrogen oxides) is considerably lower than for anthropogenic aerosols because of dry deposition.

- A comparison to AERONET AOD measurements shows a serious underestimation of the modelled AOD values. We showed that a significant downscaling of the wet-removal rates in the model is required to bring the model closer to the observations. This, however, significantly raises the modelled surface sulphate and sea salt concentrations, while other components are little affected. The modelled Ångström parameter is little affected, which indicates that the aerosol size distribution remains roughly the same.

- We have shown that, apart from uncertainties with the wet removal, large uncertainties arise from inaccurate emission inventories. We were able to significantly improve the modelled AOD at Minsk in April and May 2006 by replacing the GFED climatologic fire emissions by a tailored fire emission inventory that is based on daily fire counts. 
Based on this study, future model developments will target at improving the aerosol wet-deposition parameterisation in the TM5 model and the aerosol emission inventories. TM5 employs multiple resolutions at the same time, which calls for a fundamental approach of resolution-dependent processes like the wet removal of aerosols. Fire emissions, but also the emissions of aerosol precursors such as $\mathrm{NH}_{3}$ exhibit day-to-day variability and diurnal emission patterns that should be taken into account to enable a sound comparison to observations. Finally, it is recommended to continue intermodel (Wilson et al., 2001; Bauer et al., 2008; de Meij et al., 2006) comparisons based on budget analysis as presented in this paper or similar techniques (Textor et al., 2006).

Acknowledgements. This work benefited from measurements by the Programme for Monitoring and Evaluation of the Longrange Transmission of Air Pollutants in Europe (EMEP) and the Aerosol Robotic Network (AERONET). We thank the principal investigators of these networks and their staff for establishing and maintaining the sites used in this investigation. This research received financial support from the BOP (Policy supporting programme for particulate matter). We would like to thank the NCF (Foundation of national computer facilities) for providing the ability to run TM5 on the supercomputer Huygens. We would like to thank Olivier Boucher for programming Mie scattering calculations for aerosol distributions. M. Kahnert was supported by the Swedish Research Council under contract number 80438701 .

Edited by: Y. Balkanski

\section{References}

Anderson, T. L., Charlson, R. J., Schwartz, S. E., Knutti, R., Boucher, O., Rodhe, H., and Heintzenberg, J.: Climate forcing by aerosols - a hazy picture, Science, 300, 1103-1104, doi: 10.1126/science. $1084777,2003$.

Andres, R. J. and Kasgnoc, A. D.: A time-averaged inventory of subaerial volcanic sulfur emissions, J. Geophys. Res., 103, 25251-25261, doi:10.1029/98JD02091, 1998.

Ångström, A. K.: On the atmospheric transmission of sun radiation and on the dust in the air, Geogr. Ann., 11, 156-166, 1929.

Balkanski, Y. J., Jacob, D. J., Gardner, G. M., Graustein, W. C., and Turekian, K. K.: Transport and residence times of tropospheric aerosols inferred from a global trhee-dimensional simulation of ${ }^{210} \mathrm{~Pb}$., J. Geophys. Res., 98, 20573-20586, doi: 10.1029/93JD2456, 1993.

Barber, P. W. and Hill, S. C.: Light scattering by particles: Computational Methods, Advanced series in applied physics, World Scientific, 2, 261 pp., 1990.

Bauer, S. E., Wright, D. L., Koch, D., Lewis, E. R., McGraw, R., Chang, L.-S., Schwartz, S. E., and Ruedy, R.: MATRIX (Multiconfiguration Aerosol TRacker of mIXing state): an aerosol microphysical module for global atmospheric models, Atmos. Chem. Phys., 8, 6003-6035, doi:10.5194/acp-8-60032008, 2008.

Berkvens, P. J. F., Botchev, M. A., Lioen, W. M., and Verwer, J. G.: A Zooming Technique for Wind Transport of Air Pollu- tion, in: Finite volumes for complex applications: problems and perspectives: internation symposium, Duisburg, Germany, 499$506,1999$.

Bond, T. C., Streets, D. G., Yarber, K. F., Nelson, S. M., Woo, J.H., and Klimont, Z.: A technology-based global inventory of black and organic carbon emissions from combustion, J. Geophys. Res., 109, D14203, doi:10.1029/2003JD003697, 2004.

Bond, T. C., Habib, G., and Bergstrom, R. W.: Limitations in the enhancement of visible light absorption due to mixing state, J. Geophys. Res., 111, D20211, doi:10.1029/2006JD007315, 2006.

Boucher, O.: On Aerosol Direct Shortwave Forcing and the Henyey-Greenstein Phase Function, J. Atmos. Sci., 55, 128 134, doi:10.1175/1520-0469(1998)055〈0128:OADSFA) 2.0.CO; 2, 1997.

Bouwman, A. F., Lee, D. S., Asman, W. A. H., Dentener, F. J., van der Hoek, K. W., and Olivier, J. G. J.: A global highresolution emission inventory for ammonia, Global Biogeochem. Cy., 11(4), 561-587, doi:10.1029/97GB02266, 1997.

Bregman, B., Segers, A., Krol, M., Meijer, E., and van Velthoven, P.: On the use of mass-conserving wind fields in chemistry-transport models, Atmos. Chem. Phys., 3, 447-457, doi:10.5194/acp-3-447-2003, 2003.

Bruggeman, D. A. G.: Berechnung verscheidener physikalischer Konstanten von heterogenen Substanzen, 1. Dielektrizitätskonstanten und Leitfähigkeiten der Mischkörper aus isotropen Substanzen, Ann. Phys., 416, 636-664, doi:10.1002/ andp.19354160802, 1935.

Brunekreef, B. and Holgate, S. T.: Air pollution and health, Lancet, 360, 1233-1242, doi:10.1016/S0140-6736(02)11274-8, 2002.

Buijsman, E., Maas, H. F. M., and Asman, W. A. H.: Anthropogenic $\mathrm{NH}_{3}$ emissions in Europe, Atmos. Environ., 21, 1009-1022, doi: 10.1016/0004-6981(87)90230-7, 1987.

Chen, Y., Li, Q., Randerson, J. T., Lyons, E. A., Kahn, R. A., Nelson, D. L., and Diner, D. J.: The sensitivity of CO and aerosol transport to the temporal and vertical distribution of North American boreal fire emissions, Atmos. Chem. Phys., 9, 6559-6580, doi:10.5194/acp-9-6559-2009, 2009.

Cheng, Y. H. and Tsai, C. J.: Evaporation loss of ammonium nitrate particles during filter sampling, J. Aerosol Sci., 28, 1553-1567, doi:10.1016/S0021-8502(97)00033-5, 1997.

Chin, M., Rood, R. B., Lin, S.-J., Müller, J.-F., and Thompson, A. M.: Atmospheric sulfur cycle simulated in the global model GOCART: Model description and global properties, J. Geophys. Res., 105, 24671-24687, 2000.

Cofala, J., Amann, M., and Mechler, R.: Scenarios of world anthropogenic emissions of air pollutants and methane up to 2030 Tech. rep., International Institute for Applied System Analysis (IIASA), Laxenburg, Austria, online available at: http://www. iiasa.ac.at/rains/global_emiss/global_emiss.html, (last access: 97-2009), 2005

Dana, M. T. and Hales, J. M.: Statistical aspects of the washout of polydisperse aerosols, Atmos. Environ., 10, 45-50, doi:10.1016/ 0004-6981(76)90258, 1976.

Dentener, F. and Crutzen, P. J.: A Three-dimensional Model of the global ammonia cycle, J. Atmos. Chem., 19, 331-369, doi:10. 1007/FG00694492, 1994.

Dentener, F., Kinne, S., Bond, T., Boucher, O., Cofala, J., Generoso, S., Ginoux, P., Gong, S., Hoelzemann, J. J., Ito, A., Marelli, L., Penner, J. E., Putaud, J.-P., Textor, C., Schulz, M., van der Werf, 
G. R., and Wilson, J.: Emissions of primary aerosol and precursor gases in the years 2000 and 1750 prescribed data-sets for AeroCom, Atmos. Chem. Phys., 6, 4321-4344, doi:10.5194/acp6-4321-2006, 2006.

Dockery, D., Pope, C. A., Xu, X., Spengler, J. D., Ware, J. H., Fay, M. E., Ferris, B. G., and Speizer, F. E.: An association between air pollution and mortality in siz US cities, New Engl. J. Med., 329, 1753-1759, doi:10.1056/NEJM199312093292401, 1993.

European Monitoring and Evaluation Programma: Hjellbrekke, A.G., and Fjæraa, A. M.: Data report 2006: Acidifying and eutrophying compounds and particulate matter, Tech. rep., 2008.

Ganzeveld, L., Lelieveld, J., and Roelofs, G.-J.: A dry deposition parameterization for sulfur oxides in a chemistry and general circulation model, J. Geophys. Res., 103, 5679-5694, doi: 10.1029/97JD03077, 1998.

von Glasgow, R.: Pollution meets sea salt, Nat. Geosci., 1, 292-293, doi:10.1038/ngeo192, 2008.

Gong, S. L.: A parameterization of sea-salt aerosol source function for sub- and super-micron particles, Global Biogeochem. Cy., 17, 1097, doi:10.1029/2003GB002079, 2003.

Guelle, W., Balkanski, Y. J., Schultz, M., Dulac, F., and Monfray, P.: Wet deposition in a global size-dependent aerosol transport model 1. Comparison of a 1 year ${ }^{210} \mathrm{~Pb}$ simulation with ground measurements, J. Geophys. Res., 103, 28875-28891, 1998.

Halmer, M. M., Schmincke, H.-U., and Graf, H.-F.: The annual volcanic gas input into the atmosphere, in particular into the stratosphere: a global data set for the past 100 years, J. Volcanol. Geoth. Res., 115, 511-528, doi:10.1016/S0377-0273(01) 00318-3, 2002.

Haywood, J. and Boucher, O.: Estimates of the direct and indirect radiative forcings due to tropospheric aerosols: a review, Rev. Geophys., 38, 513-543, 2000.

Hess, M., Koepke, P., and Schult, I.: Optical Properties of Aerosols and Clouds: The Software Package OPAC, B. Am. Meteorol. Soc., 79, 831-844, doi:10.1175/1520-0477(1998)079<0831: OPOAAC) 2.0.CO;2, 1998.

Hicks, B. B., Wesely, M. L., Coulter, R. L., Hart, R. L., Durham, J. L., Speer, R., and Stedman, D. H.: An experimental study of sulfur and $\mathrm{NO}_{\mathrm{x}}$ fluxes over grassland, Bound. Lay. Meteorol., 34, 103-121, 1986.

Hoek, G., Brunekreef, B., Goldbohm, S., Fischer, P., and van den Brandt, A.: Association between mortality and indicators of traffic-related air pollution in the Netherlands: a cohort study, Lancet, 360, 1203-1209, doi:10.1016/S0140-6736(02)11280-3, 2002.

Holben, B. N., Tenré, D., Smirnov, A., Eck, T. F., Slutsker, I., Abuhassan, N., Newcomb, W. W., Schafer, J. S., Chatenet, B., Lavenu, F., Kaufman, Y. J., Vande Castle, J., Setzer, A., Markham, B., Clark, D., Frouin, R., Halthore, R., Karneli, A., O’Neill, N. T., Pietras, C., Pinker, R. T., Voss, K., and Zibordi, G.: An emerging ground-based aerosol climatology: Aerosol optical depth from AERONET, J. Geophys. Res., 106, 1206712097, 2001.

Holtslag, A. A. M. and Boville, B. A.: Local versus nonlocal boundary-layer diffusion in a global climate model, J. Climate, 6 , 1825-1842, doi:10.1175/1520-0442(1993)006〈1825:LVNBLD $\rangle$ 2.0.CO;2, 1993.

Houweling, S., Dentener, F., and Lelieveld, J.: The impact of nonmethane hydrocarbon compounds on tropospheric photochem- istry, J. Geophys. Res., 103, 10673-10696, 1998.

Intergovernmental Panel on Climate Change: edited by: Nakicenovic, N., Akamo, J., Davis, G., de Vries, B., Fenhann, J., Gaffin, S., Gregory, K., Grübler, A., Jung, T. Y., Kram, T., La Rovere, E. L., Michaelis, L., Mori, S., Morita, T., Pepper, W., Pitcher, H., Price, L., Riaki, K., Roehrl, A., Rogner, H.-H., Sankovski, A., Schlesinger, M., Shukla, P., Smith, S., Swart, R., van Rooijen, S., Victor, N., and Dadi, Z.: Special report on Emissions Scenarios, 2000.

Intergovernmental Panel on Climate Change, edited by: Solomon, S., Qin, D., Manning, M., Chen, Z., Marquis, M., Averyt, K. B., Tignor, M., and Miller, H. L.: Climate change 2007: The physical Science Basis, IPCC Fourth Assassement report (AR4), 2007.

Kahnert, M.: Modelling the optical and radiative properties of freshly emitted light absorbing carbon within an atmospheric chemical transport model, Atmos. Chem. Phys., 10, 1403-1416, doi:10.5194/acp-10-1403-2010, 2010a.

Kahnert, M.: Numerically exact computations of the optical properties of light absorbing carbon aggregates for wavelength of $200 \mathrm{~nm}-12.2 \mu \mathrm{m}$, Atmos. Chem. Phys., 10, 8319-8329, doi:10.5194/acp-10-8319-2010, 2010b.

Kanakidou, M.: Aerosols in Global Models - Focus on Europe, in: Regional Climate Variability and its Impacts in The Mediterranean Area, chap. 4, Springer, The Netherlands, 143-154, 2007.

Kanakidou, M., Seinfeld, J. H., Pandis, S. N., Barnes, I., Dentener, F. J., Facchini, M. C., Van Dingenen, R., Ervens, B., Nenes, A., Nielsen, C. J., Swietlicki, E., Putaud, J. P., Balkanski, Y., Fuzzi, S., Horth, J., Moortgat, G. K., Winterhalter, R., Myhre, C. E. L., Tsigaridis, K., Vignati, E., Stephanou, E. G., and Wilson, J.: Organic aerosol and global climate modelling: a review, Atmos. Chem. Phys., 5, 1053-1123, doi:10.5194/acp-5-1053-2005, 2005.

Kaufman, Y. J., Tenré, D., and Boucher, O.: A satellite view of aerosols in the climate system, Nature, 419, 215-223, 2002.

Kerkweg, A., Buchholz, J., Ganzeveld, L., Pozzer, A., Tost, H., and Jöckel, P.: Technical Note: An implementation of the dry removal processes DRY DEPosition and SEDImentation in the Modular Earth Submodel System (MESSy), Atmos. Chem. Phys., 6, 4617-4632, doi:10.5194/acp-6-4617-2006, 2006.

Kinne, S., Lohmann, U., Feichter, J., Schultz, M., Timmreck, C., Ghan, S., Easter, R., Chin, M., Ginoux, P., Takemura, T., Tegen, I., Koch, D., Herzog, M., Penner, J., Pitari, G., Holben, B., Eck, T., Smirnov, A., Dubovik, O., Slutsker, I., Tanre, D., Tarnes, O., Mishchenko, M., Geogdzhayev, I., Chu, D. A., and Kaufman, Y.: Monthly averages of aerosol properties: A global comparison among models, satellite data and AERONET ground data, J. Geophys. Res., 108, 2634, doi:10.1029/2001JD001253, 2003.

Korhonen, H., Carslaw, K. S., Spracklen, D. V., Ridley, D. A., and Ström, J.:A global model study of processes controlling aerosol size distributions in the Arctic spring and summer, J. Geophys. Res., 113, D08211, doi:10.1029/2007JD009114, 2008.

Krol, M., Houweling, S., Bregman, B., van den Broek, M., Segers, A., van Velthoven, P., Peters, W., Dentener, F., and Bergamaschi, P.: The two-way nested global chemistry-transport zoom model TM5: algorithm and applications, Atmos. Chem. Phys., 5, 417432, doi:10.5194/acp-5-417-2005, 2005.

Krol, M. C. and van Weele, M.: Implications of variations in photodissociation rates for global tropospheric chemistry, Atmos. Environ., 31, 1257-1273, doi:10.1016/S1352-2310(96)00323-8, 
1997.

Landgraf, J. and Crutzen, P. J.: An efficient method for online calculations of photolysis and heating rates, J. Atmos. Sci., 55, 863-878, doi:10.1175/1520-0469(1998)055〈0863:AEMFOC $\rangle$. $0 . \mathrm{CO} ; 2,1998$.

Langner, J. and Rodhe, H.: A global Three-dimensional Model of the tropospheric Sulfur cycle, J. Atmos. Chem., 13, 225-263, doi:10.1007/BF00058134, 1991.

Lazaridis, M., Semb, A., Larssen, S., Hov, Ø., Hansen, J. E., Schaug, J., and Tørseth, K.: Measurements of particulate matter within the framework of the European Monitoring and Evaluation Programme (EMEP) 1. First results, Sci. Total Environ., 285, 209-235, doi:10.1016/S0048-9697(01)00932-9, 2002.

Lee, Y. H. and Adams, P. J.: Evaluation of aerosol distributions in the GISS-TOMAS global aerosol microphysics model with remote sensing observations, Atmos. Chem. Phys., 10, 2129-2144, doi:10.5194/acp-10-2129-2010, 2010.

van Loon, M., Vautard, R., Schaap, M., Bergström, R., Bessagnet, B., Brandt, J., Builtjes, P. J. H., Christensen, J. H., Cuvelier, C., Graff, A., Jonson, J. E., Krol, M., Langner, J., Roberts, P., Rouil, L., Stern, R., Tarrasón, L., Thunis, P., Vignati, E., White, L., and Wind, P.: Evaluation of long-term ozone simulations from seven regional air quality models and their ensemble, Atmos. Environ., 41, 2083-2097, doi:10.1016/j.atmosenv.2006.10.073, 2007.

Louis, J. F.: A parametric model of vertical eddy fluxes in the atmosphere, Bound. Lay. Meteorol., 17, 187-202, doi:10.1007/ FG00117978, 1979.

Manders, A. M. M., Schaap, M., Querol, X., Albert, M. F. M. A., Vercauteren, J., Kuhlbusch, T. A. J., and Hoogerbrugge, R.: Sea salt concentrations across the European continent, Atmos. Environ., 44, 2434-2442, doi:10.1016/j.atmosenv.2010.03.028, 2010.

Maxwell-Garnett, J. C.: Colours in metal glasses and in metallic films, Philos. T. Roy. Soc. Lond. A, 203, 385-420, doi:10.1098/ rsta.1904.0024, 1904.

Mehlmann, A. and Warneck, P.: Atmospheric gaseous $\mathrm{HNO}_{3}$, particulate nitrate, and aerosol size distribution of major ionic species at a rural site in Western Germany, Atmos. Environ., 29, 2359-2373, doi:10.1016/1352-2310(95)00056-5, 1995.

de Meij, A., Krol, M., Dentener, F., Vignati, E., Cuvelier, C., and Thunis, P.: The sensitivity of aerosol in Europe to two different emission inventories and temporal distribution of emissions, Atmos. Chem. Phys., 6, 4287-4309, doi:10.5194/acp-6-4287-2006, 2006.

Metzger, S., Dentener, F., Krol, M., Jeuken, A., and Lelieveld, J.: Gas/aerosol partitioning 2: Global modeling results, J. Geophys. Res., 107, 4313, doi:10.1029/2001JD001103, 2002a.

Metzger, S., Dentener, F., Pandis, S., and Lelieveld, J.: Gas/aerosol partitioning 1: A computationally efficient model, J. Geophys. Res., 107, 4312, doi:10.1029/2001JD001102, 2002b.

Mie, G.: Beiträge zur Optik trüber Medien, speziell kolloidaler Metallösungen, Ann. Phys., 330, 377-445, doi:10.1002/andp. 19083300302, 1908

Millero, F. J.: Physicochemical controls on seawater, chap. 6.01, Elsevier, Amsterdam, The Netherlands, 1-21, 2004.

Nenes, A., Pandis, S. N., and Pilins, C.: ISORROPIA: A new thermodynamic equilibrium model for multiphase multicomponent inorganic aerosols, Aquat. Geochem., 4, 123-152, 1998.

Pickering, K. E., Wang, Y., Tao, W.-K., Price, C., and Müller, J.F.: Vertical distributions of lightning $\mathrm{NO}_{\mathrm{x}}$ for use in regional and global chemical transport models, J. Geophys. Res., 103, 31203 31216, 1998.

Pope, C. A., Dockery, D. W., and Schwartz, J.: Review of Epidemiological Evidence of Health Effects of Particulate Air Pollution, Inhal. Toxicol., 7, 1-18, doi:10.3109/08958379509014267, 1995.

Prather, J.: Numerical Advection by Conservation of Second-Order Moments, J. Geophys. Res., 91, 6671-6681, 1986.

Pringle, K. J., Tost, H., Messina, S., Steil, B., Giannadaki, D., Nenes, A., Fountoukis, C., Stier, P., Vignati, E., and Lelieveld, J: Description and evaluation of GMXe: a new aerosol submodel for global simulations (v1), Geosci. Model Dev., 3, 391-412, doi:10.519/gmd-3-391-2010, 2010.

Putaud, J.-P., Raes, F., van Dingenen, R., Brüggemann, E., Facchini, M.-C., Decesari, S., Fuzzi, S., Gehrig, R., Hüglin, C., Laj, P., Lorbeer, G., Maenhaut, W., Mihalopoulos, N., Müller, K., Querol, X., Rodriguez, S., Schneider, J., Spindler, G., ten Brink, H., Tørseth, K., and Wiedensohler, A.: A European aerosol phenomenology-2: chemical characteristics of particulate matter at kerbside, urban, rural and background sites in Europe, Atmos. Environ., 38, 2579-2595, doi:10.1016/j.atmosenv.2004.01.041, 2004.

Randerson, J. T., van der Werf, G. R., Giglio, L., Collatz, G. J., and Kasibhatla, P. S.: Global Fire Emission Database, Version 2 (GFEDv2), Data set. Available on-line http://daac.ornl.gov/ (last access 9-7-2009) from Oak Ridge National Laboratory Distributed Active Archive Center, Oak Ridge, Tennessee, USA, doi:10.3334/ORNLDAAC/834, 2006.

Roelofs, G.-J. and Lelieveld, J.: Distribution and budget of $\mathrm{O}_{3}$ in the troposphere calculated with a chemistry general circulation model, J. Geophys. Res., 100, 20983-20998, 1995.

Rosenfeld, D., Lohmann, U., Raga, G. B., O’Dowd, C. D., Kulmala, M., Fuzzi, S., Reissell, A., and Andreae, M. O.: Flood or Drought: How Do Aerosols Affect Precipitation?, Science, 321, 1309-1313, doi:10.1126/science.1160606, 2008.

Russell, G. F. and Lerner, J. A.: A New Finite-Differencing Scheme for the Tracer Transport Equation, J. Appl. Meteorol., 20, 1483-1498, doi:10.1175/1520-0450(1981)020〈1483:ANFDSF $\rangle$ 2.0.CO;2, 1981.

Russell, P. B., Bergstrom, R. W., Shinozuka, Y., Clarke, A. D., DeCarlo, P. F., Jimenez, J. L., Livingston, J. M., Redemann, J., Dubovik, O., and Strawa, A.: Absorption Angstrom Exponent in AERONET and related data as an indicator of aerosol composition, Atmos. Chem. Phys., 10, 1155-1169, doi:10.5194/acp10-1155-2010, 2010.

Saarikoski, S., Sillanpää, M., Sofiev, M., Timonen, H., Saarnio, K., Teinilä, K., Karppinen, A., Kukkonen, J., and Hillamo, R.: Chemical composition of aerosols during a major biomass burning episode over northern Europe in spring 2006: Experimental and modelling assessments, Atmos. Environ., 41, 3577-3589, doi:10.1016/j.atmosenv.2006.12.053, 2007.

von Salzen, K.: Piecewise log-normal approximation of size distributions for aerosol modelling, Atmos. Chem. Phys., 6, 13511372, doi:10.5194/acp-6-1351-2006, 2006

Santee, M. L., Read, W. G., Waters, J. W., Froidevaux, L., Manney, G. L., Flower, D. A., Jarnot, R. F., Harwood, R. S., and Peckham, G. E.: Interhemispheric Differences in Polar Stratospheric $\mathrm{HNO}_{3}, \mathrm{H}_{2} \mathrm{O}, \mathrm{ClO}$ and $\mathrm{O}_{3}$, Science, 267, 849-852, doi: 10.1126/science.267.5199.849, 1995. 
Schaap, M., Müller, K., and ten Brink, H. M.: Constructing the European aerosol nitrate concentration Field from quality analysis data, Atmos. Environ., 36, 1323-1335, doi:10.1016/ S1352-231(01)00556-8, 2002.

Schaap, M., van Loon, M., ten Brink, H. M., Dentener, F. J., and Builtjes, P. J. H.: Secondary inorganic aerosol simulations for Europe with special attention to nitrate, Atmos. Chem. Phys., 4, 857-874, doi:10.5194/acp-4-857-2004, 2004a.

Schaap, M., Spindler, G., Schultz, M., Acker, K., Maenhaut, W., Berner, A., Wieprecht, W., Streit, N., Müller, K., Brüggemann, E., Chi, X., Putaud, J.-P., Hitzenberger, R., Puxbaum, H., Baltensperger, U., and ten Brink, H.: Artefacts in the sampling of nitrate studied in the "INTERCOMP" campaigns of EUROTRACAEROSOL, Atmos. Environ., 38, 6487-6496, doi:10.1016/j. atmosenv.2004.08.026, 2004b.

Segelstein, D. J.: The complex refractive index of water, Master's thesis, University of Missouri-Kansas City, USA, 1981.

Segers, A., Velthoven, P. V., Bregman, B., and Krol, M.: On the Computation of Mass Fluxes for Eulerian Transport Models from Spectral Meteorological Fields, in: ICCS'02: Proceedings of the International Conference on Computational Science-Part II, Springer-Verlag, London, UK, 767-776, 2002.

Seibert, P. and Frank, A.: Source-receptor matrix calculation with a Lagrangian particle dispersion model in backward mode, Atmos. Chem. Phys., 4, 51-63, doi:10.5194/acp-4-51-2004, 2004.

Seinfeld, J. H.: Atmospheric Chemistry and Physics of Air Pollution, Wiley-Interscience, 1986.

Sihto, S.-L., Kulmala, M., Kerminen, V.-M., Dal Maso, M., Petäjä, T., Riipinen, I., Korhonen, H., Arnold, F., Janson, R., Boy, M., Laaksonen, A., and Lehtinen, K. E. J.: Atmospheric sulphuric acid and aerosol formation: implications from atmospheric measurements for nucleation and early growth mechanisms, Atmos. Chem. Phys., 6, 4079-4091, doi:10.5194/acp-6-4079-2006, 2006.

Sihto, S.-L., Vuollekoski, H., Leppä, J., Riipinen, I., Kerminen, V.M., Korhonen, H., Lehtinen, K. E. J., Boy, M., and Kulmala, M.: Aerosol dynamics simulations on the connection of sulphuric acid and new particle formation, Atmos. Chem. Phys., 9, 29332947, doi:10.5194/acp-9-2933-2009, 2009.

Slinn, S. A. and Slinn, W. G. N.: Predictions for particle deposition on natural waters, Atmos. Environ., 14, 1013-1016, doi:10.1016/ 0004-6981(80)90032-3, 1980.

Sofiev, M., Vankevich, R., Lotjonen, M., Prank, M., Petukhov, V., Ermakova, T., Koskinen, J., and Kukkonen, J.: An operational system for the assimilation of the satellite information on wildland fires for the needs of air quality modelling and forecasting, Atmos. Chem. Phys., 9, 6833-6847, doi:10.5194/acp-9-68332009, 2009.

Sternbeck, J., Sjödin, Å., and Andréasson, K.: Metal emissions from road traffic and the influence of resuspension - results from two tunnel studies, Atmos. Environ., 36, 4735-4744, doi: 10.1016/S1352-2310(02)00561-7, 2002.

Stier, P., Feichter, J., Kinne, S., Kloster, S., Vignati, E., Wilson, J., Ganzeveld, L., Tegen, I., Werner, M., Balkanski, Y., Schulz, M., Boucher, O., Minikin, A., and Petzold, A.: The aerosolclimate model ECHAM5-HAM, Atmos. Chem. Phys., 5, 11251156, doi:10.5194/acp-5-1125-2005, 2005.

Stone, V. and Donaldson, K.: Small particles - Big problem, Aerosol Soc. Newslett., 33, 12-14, 1998.
Textor, C., Schulz, M., Guibert, S., Kinne, S., Balkanski, Y., Bauer, S., Berntsen, T., Berglen, T., Boucher, O., Chin, M., Dentener, F., Diehl, T., Easter, R., Feichter, H., Fillmore, D., Ghan, S., Ginoux, P., Gong, S., Grini, A., Hendricks, J., Horowitz, L., Huang, P., Isaksen, I., Iversen, I., Kloster, S., Koch, D., KirkevÅg, A., Kristjansson, J. E., Krol, M., Lauer, A., Lamarque, J. F., Liu, X., Montanaro, V., Myhre, G., Penner, J., Pitari, G., Reddy, S., Seland, Ø., Stier, P., Takemura, T., and Tie, X.: Analysis and quantification of the diversities of aerosol life cycles within AeroCom, Atmos. Chem. Phys., 6, 1777-1813, doi:10.5194/acp6-1777-2006, 2006.

Tiedtke, M.: A Comprehensive Mass Flux Scheme for Cumulus Parameterization in Large-Scale Models, Mon. Weather Rev., 117, 1779, doi:10.1175/1520-0493(1989)117〈1779:ACMFSF $\rangle$. $0 . \mathrm{CO} ; 2,1989$.

Vecchi, R., Valli, G., Fermo, P., D’Allessandro, A., Pizzalunga, A., and Bernardoni, V.: Organic and inorganic sampling artefacts assessment, Atmos. Environ., 43, 1713-1720, doi:10.1016/ j.atmosenv.2008.12016, 2009.

Vehkamäki, H., Kulmala, M., Napari, I., Lehtinen, K. E. J., Timmreck, C., Noppel, M., and Laaksonen, A.: An improved parameterization for sulfuric acid - water nucleation rates for tropospheric and stratospheric conditions, J. Geophys. Res., 107, 4622, doi:10.1029/2002JD002184, 2002.

Vignati, E., Wilson, J., and Stier, P.: M7: An efficient sizeresolved aerosol microphysics module for large-scale aerosol transport models, J. Geophys. Res., 109, D22202, doi:10.1029/ 2003JD004485, 2004.

Vignati, E., Facchini, M. C., Rinaldi, M., Scannell, C., Ceburnus, D., Sciare, J., Kanakidou, M., Myriokefalitakis, S., Dentener, F., and O'Dowd, C. D.: Global scale emission and distribution of sea-spray aerosol: Sea-salt and organic enrichment, Atmos. Environ., 44, 670-677, doi:10.1016/j.atmosenv.2009.11.013, 2010a.

Vignati, E., Karl, M., Krol, M., Wilson, J., Stier, P., and Cavalli, F.: Sources of uncertainties in modelling black carbon at the global scale, Atmos. Chem. Phys., 10, 2595-2611, doi:10.5194/acp-102595-2010, 2010b.

Volkamer, R., Jizenez, J. L., San Martini, F., Dzepina, K., Zhang, Q., Salcedo, D., Molina, L. T., Worsnop, D. R., and Molina, M. J.: Secondary organic aerosol formation from anthropogenic air pollution: Rapid and higher than expected, Geophys. Res. Lett., 33, LT17811, doi:10.1029/2006GL026899, 2006.

van der Werf, G. R., Randerson, J. T., Giglio, L., Collatz, G. J., Kasibhatla, P. S., and Arellano Jr., A. F.: Interannual variability in global biomass burning emissions from 1997 to 2004, Atmos. Chem. Phys., 6, 3423-3441, doi:10.5194/acp-6-3423-2006, 2006.

Wichink Kruit, R. J., van Pul, W. A. J., Otjes, R. P., Hofschreuder, P., Jacobs, A. F. G., and Holtslag, A. A. M.: Ammonia fluxes and derived canopy compensation points over non-fertilized agricultural grassland in The Netherlands using the new gradient ammonia - high accuracy - monitor (GRAHAM), Atmos. Environ., 41, 1275-1287, doi:10.1016/j.atmosenv.2006.09.039, 2007.

Williams, J. E. and van Noije, T. P. C.: On the updating of the modified Carbon Bond Mechanism IV for use in global Chemistry Transport Models, Tech. Rep. TR 2008-02, KNMI, De Bilt, The Netherlands, 2008.

Wilson, J., Cuvelier, C., and Raes, F.: A modeling study of global mixed aerosol fields, J. Geophys. Res., 106, 34081-34108, 2001. 
Yttri, K. E., Aas, W., Bjerke, A., Cape, J. N., Cavalli, F., Ceburnis, D., Dye, C., Emblico, L., Facchini, M. C., Forster, C., Hanssen, J. E., Hansson, H. C., Jennings, S. G., Maenhaut, W., Putaud, J. P., and Tørseth, K.: Elemental and organic carbon in $\mathrm{PM}_{10}$ : a one year measurement campaign within the European Monitoring and Evaluation Programme EMEP, Atmos. Chem. Phys., 7, 5711-5725, doi:10.5194/acp-7-5711-2007, 2007.
Yu, X.-Y., Lee, T., Ayres, B., Kreidenweis, S. M., Malm, W., and Collett, J. L. J.: Loss of fine particulate ammonium from denuded nylon filters, Atmos. Environ., 40, 4797-4807, doi: 10.1016/j.atmosenv.2006.03.061, 2006.

Zhang, X. and McMurry, P. H.: Evaporative losses of fine particulate nitrates during sampling, Atmos. Environ., 26A, 3305-3312, 1992. 